\title{
The imprint of hydrothermal fluids on trace-element contents in white mica and tourmaline from the Panasqueira W-Sn-Cu deposit, Portugal
}

\author{
Marta S. Codeço ${ }^{1,2}$ (1D $\cdot$ Philipp Weis ${ }^{1,2} \cdot$ Robert B. Trumbull $^{1} \cdot$ Vincent Van Hinsberg $^{3} \cdot$ Filipe Pinto $^{4} \cdot$ \\ Pilar Lecumberri-Sanchez ${ }^{5} \cdot$ Anja M. Schleicher ${ }^{1,2}$
}

Received: 21 November 2019 / Accepted: 28 April 2020 / Published online: 21 May 2020

(C) The Author(s) 2020

\begin{abstract}
White mica and tourmaline are the dominant hydrothermal alteration minerals at the world-class Panasqueira W-Sn$\mathrm{Cu}$ deposit in Portugal. Thus, understanding the controls on their chemical composition helps to constrain ore formation processes at this deposit and determine their usefulness as pathfinder minerals for mineralization in general. We combine whole-rock geochemistry of altered and unaltered metasedimentary host rocks with in situ LA-ICP-MS measurements of tourmaline and white mica from the alteration halo. Principal component analysis (PCA) is used to better identify geochemical patterns and trends of hydrothermal alteration in the datasets. The hydrothermally altered metasediments are enriched in $\mathrm{As}, \mathrm{Sn}, \mathrm{Cs}, \mathrm{Li}, \mathrm{W}, \mathrm{F}, \mathrm{Cu}, \mathrm{Rb}, \mathrm{Zn}, \mathrm{Tl}$, and $\mathrm{Pb}$ relative to unaltered samples. In situ mineral analyses show that most of these elements preferentially partition into white mica over tourmaline ( $\mathrm{Li}, \mathrm{Rb}, \mathrm{Cs}, \mathrm{Tl}, \mathrm{W}$, and $\mathrm{Sn}$ ), whereas $\mathrm{Zn}$ is enriched in tourmaline. White mica has distinct compositions in different settings within the deposit (greisen, vein selvages, wall rock alteration zone, late fault zone), indicating a compositional evolution with time. In contrast, tourmaline from different settings overlaps in composition, which is ascribed to a stronger dependence on host rock composition and also to the effects of chemical zoning and microinclusions affecting the LA-ICP-MS analyses. Hence, in this deposit, white mica is the better recorder of the fluid composition. The calculated trace-element contents of the Panasqueira mineralizing fluid based on the mica data and estimates of mica-fluid partition coefficients are in good agreement with previous fluidinclusion analyses. A compilation of mica and tourmaline trace-element compositions from Panasqueira and other W-Sn deposits shows that white mica has good potential as a pathfinder mineral, with characteristically high Li, Cs, $\mathrm{Rb}, \mathrm{Sn}$, and $\mathrm{W}$ contents. The trace-element contents of hydrothermal tourmaline are more variable. Nevertheless, the compiled data suggest that high $\mathrm{Sn}$ and Li contents are distinctive for tourmaline from W-Sn deposits.
\end{abstract}

Keywords Alteration geochemistry $\cdot$ Tourmaline $\cdot$ White mica $\cdot$ Panasqueira $\cdot$ Tungsten-tin deposits $\cdot$ Magmatic-hydrothermal systems $\cdot$ Trace elements

Editorial handling: A. R. Cabral

Electronic supplementary material The online version of this article (https://doi.org/10.1007/s00126-020-00984-8) contains supplementary material, which is available to authorized users.

Marta S. Codeço

marta.codeco@gfz-potsdam.de

1 GFZ German Research Centre for Geosciences, Telegrafenberg, 14473 Potsdam, Germany

2 Institute of Earth and Environmental Science, University of Potsdam, 14476 Potsdam, Germany
3 Department of Earth and Planetary Sciences, McGill University, Montreal H3A 0E8, Canada

4 Beralt Tin \& Wolfram (Portugal) S.A, Barroca Grande, 6225-051 Castelo Branco, Portugal

5 Department of Earth and Atmospheric Sciences, University of Alberta, Edmonton T6G 2E3, Canada 


\section{Introduction}

The alteration assemblages associated with hydrothermal deposits typically have much larger footprints than the areas containing metals at economic grades and thus constitute important exploration guides (Lowell and Guilbert 1970; Large and McGoldrick 1998; Mathieu 2018). Identifying mineral pathfinders and developing their use for exploration require studying deposits to generate a detailed understanding of what controls the mineral composition and to what extent this reflects the chemical signature of the mineralization they are associated with. In the last decades, many studies have focused on mineral exploration tools based on fertility indicators and chemical vectoring (Kerrich and Wyman 1997; Kelley et al. 2006; Jackson 2010; Cooke et al. 2014; Wilkinson et al. 2015; Champion and Huston 2016; McClenaghan and Layton-Matthews 2017; Soltani Dehnavi et al. 2018; Dill 2018; Codeço et al. 2018; Uribe-Mogollon and Maher 2018; Luz et al. 2019). In that context, there is an increasing interest in using multivariate statistics and machine learning methods (Cheng et al. 2011; Yang and Cheng 2014; Makvandi et al. 2016a, 2019; Gonçalves et al. 2018; Ordóñez-Calderón and Gelcich 2018; Grunsky and de Caritat 2019; Huang et al. 2019; Gonçalves and Mateus 2019) and in developing discriminant diagrams to separate different styles of mineralization (Dupuis and Beaudoin 2011; Montreuil et al. 2013; Makvandi et al. 2016b; Fresia et al. 2017; Huang et al. 2019).

The world-class Panasqueira W-Sn-Cu deposit in central Portugal has more than 100 years of activity and is currently Europe's second largest tungsten mine, after Felbertal, Austria (USGS 2019). The deposit consists of sub-horizontal mineralized quartz veins that are hosted by metasedimentary rocks above a late-Variscan granite and its greisen cupola (Kelly and Rye 1979; Bussink 1984; Polya et al. 2000) (Fig. 1). White mica and tourmaline are the most abundant alteration minerals throughout the deposit, occurring in both the early and late mineralization stages. Thus, these minerals are of prime interest as indicators for the composition of the mineralizing fluids and may have potential as ore pathfinders applicable to similar deposits worldwide.

Under equilibrium conditions, the composition of hydrothermal mica and tourmaline is controlled by the composition of the fluid and the partition coefficients of the elements between the mineral and fluid phase. Partition coefficients are sensitive to pressure, temperature, and element speciation in the fluid (van Hinsberg et al. 2010). Fluid composition is, in turn, sensitive to the fluid-rock ratio, with a progressively larger impact of the local host-rock composition as the fluid-rock ratio decreases. Preliminary tourmaline-fluid partition coefficients have been estimated for high-pressure subduction zone fluids (van Hinsberg et al. 2017), and tourmaline-melt partitioning was studied by van Hinsberg (2011), but no data are available at hydrothermal conditions.
Experimental studies related to mica-fluid partitioning are also limited (Bos 1990; Zhu and Sverjensky 1991; Melzer and Wunder 2001; Green and Adam 2003). Chemical variations and microstructures of mica have been used to trace the degree of differentiation and magmatic-hydrothermal processes in highly fractionated granitic and associated ore systems (Roda et al. 2007; Lichtervelde et al. 2008; Johan et al. 2012; Breiter et al. 2017, 2019). While it is debated to what degree mica can be used as a fluid tracer, recent studies suggest that the trace-element contents in mica are controlled by their presence in the fluids and by fluid-mica partition coefficients which themselves vary as a function of pressure, temperature, and chemical composition conditions (Legros et al. 2016, 2018).

In this study, we first establish the bulk chemical changes caused by hydrothermal alteration based on analyses of altered and unaltered host rocks, as well as the underlying granite and greisen. We then present in situ trace-element compositions of white mica and tourmaline from the vein selvages and the alteration zones by laser ablation ICP-MS analyses. We use principal component analysis (PCA) of the compositional data from whole rocks and minerals to help identify and interpret the geochemical effects of the hydrothermal alteration and the ability of the minerals to reflect them. The mica studied is exclusively dioctahedral but shows a range of compositions with variable muscovite-celadonite-phengite components (Codeço et al. 2019). For simplicity, we will use the terms white mica and muscovite interchangeably.

\section{The Panasqueira W-Sn-Cu deposit}

The Panasqueira deposit is located in the Iberian Massif (Fig. 1), which is part of the European Variscan Belt that formed as a result of the Laurussia-Gondwana collision through the Late Devonian (ca. $370 \mathrm{Ma}$ ), culminating with the closure of the Rheic Ocean (ca. 300 Ma) (Ribeiro et al. 1990; Kroner et al. 2007; Martínez Catalán et al. 2007). A large number of postcollisional granites in the Variscan Belt are highly evolved and several host important $\mathrm{Sn}-\mathrm{W}$ deposits, which take various forms including veins, stocks, skarns, breccia pipes, and greisen bodies (Štemprok 1980). The Iberian Massif contains one of the largest domains of granitoids in the Variscan Belt, among which is the $290 \pm 10$-Ma-old (Clark 1970) Panasqueira granite, a peraluminous, S-type, two-mica granite containing quartz, microcline, plagioclase, muscovite $>$ biotite, apatite, ilmenite, and zircon (Kelly and Rye 1979; Neiva 1987). The Panasqueira granite does not crop out at the surface but has been intersected by drilling. The granite intruded greenschist-facies biotite-chlorite-quartz schists of the Almaceda Formation, which is part of the regional SchistGreywacke Complex-Beiras Group (SGC-BG) of Late Ediacaran to Early Cambrian age (Fig. 1). A contact 


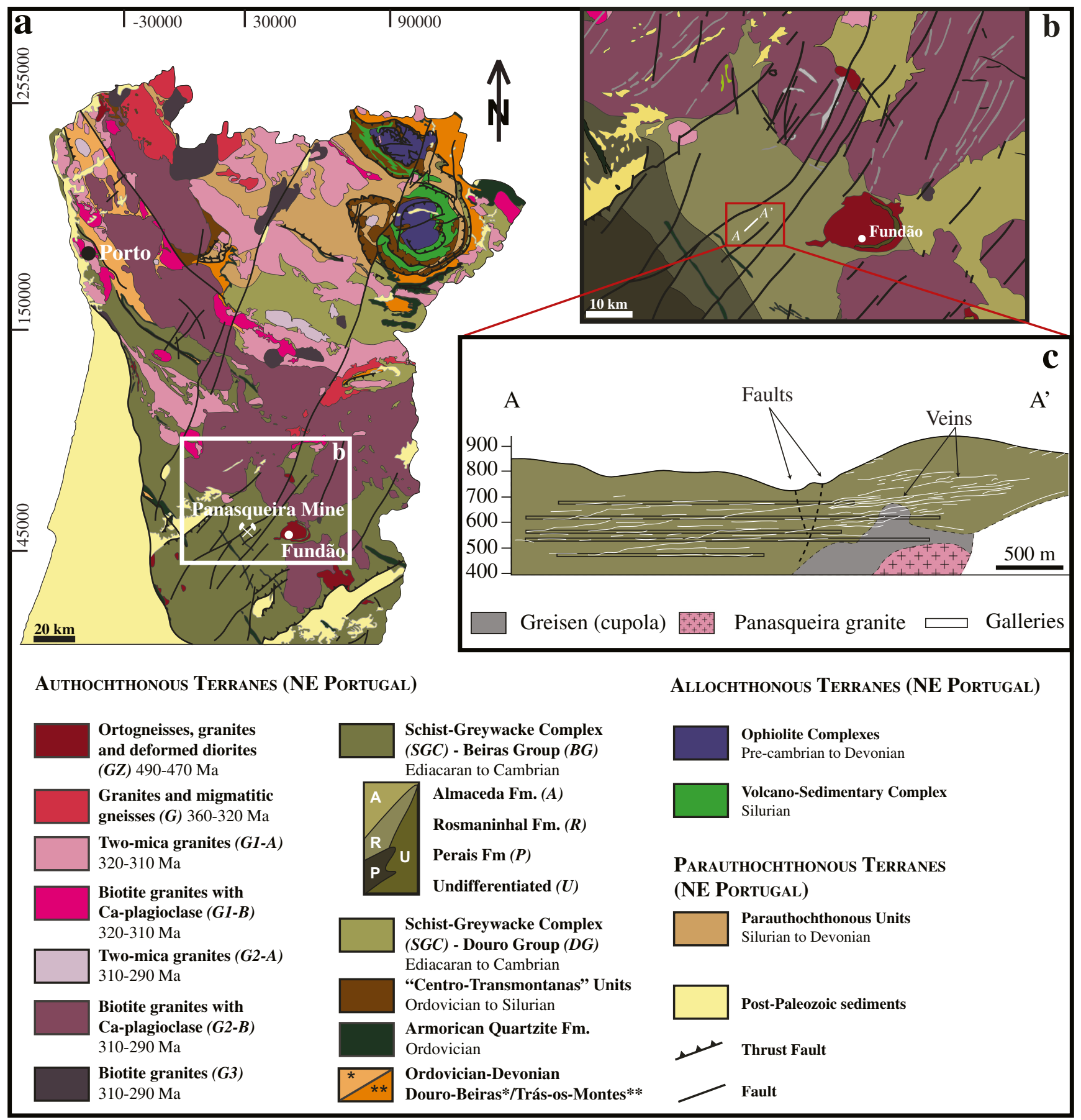

Fig. 1 Geological setting of the studied area: (a) geological map of northern and central Portugal showing the granitic suites and metasedimentary rocks (adapted from Carta Geológica de Portugal à escala 1:1,000,000 (LNEG 2010) and Carta Geológica de Portugal à escala 1:500,000 (Oliveira et al. 1992); coordinate system: ETRS89/Portugal TM06

metamorphic aureole with cordierite porphyroblasts (spotted schist) is locally developed in the mine area above the granite (Conde et al. 1971; Bussink 1984). The exposed greisen cupola of the granite (Fig. 1c) is composed of medium- to coarse-grained quartz and white mica, with minor amounts of topaz, chlorite, K-feldspar, plagioclase, pyrite,
(EPSG: 3763)); (b) geological map of the Panasqueira mine area (adapted from Carta Geológica de Portugal à escala 1:500,000 (Oliveira et al. 1992)); and (c) schematic cross section of the Panasqueira vein system, greisen and granite (modified after Thadeu (1979)]

arsenopyrite, and zircon (Kelly and Rye 1979; Bussink 1984; Neiva 1987; Codeço et al. 2019).

The flat-lying quartz-wolframite \pm cassiterite \pm sulfides \pm carbonates veins have been exposed by underground mining over an area of $2500-\mathrm{m}$ length, 400 to $2000-\mathrm{m}$ width, and at least 500-m depth (Wheeler 2016). The paragenetic sequence 
of the ore veins has been divided into six stages of mineralization: quartz-tourmaline alteration, muscovite selvage formation, main oxide-silicate stage, main sulfide stage, pyrrhotite alteration stage, and late carbonate stage. Tourmaline, white mica, and quartz coexist as gangue minerals from the early stages to the main sulfide stage (Kelly and Rye 1979; Polya 1989; Foxford et al. 1991, 2000; Polya et al. 2000). Hydrothermal alteration of the wall rocks produced concentric zones with progressively greater distance from the veins, consisting of a proximal tourmaline-quartz-muscovite zone, 2 to $30-\mathrm{cm}$ thick, containing more than 50 vol\% of tourmaline, and a distal muscovite-quartz zone including minor tourmaline or topaz (Bussink 1984). Even though muscovite and tourmaline are present in different stages at Panasqueira, we exclusively focus on the occurrences that are related to the ore-forming event in the veins and altered host rocks at the immediate vein contact.

Quartz-hosted fluid inclusions indicate that the main oxide and sulfide stages formed from fluids with low to moderate salinities $(5-10 \mathrm{wt} \% \mathrm{NaCl}$ eq.) at temperatures between 230 and $360{ }^{\circ} \mathrm{C}$, while inclusions from the late carbonate stage indicate lower temperatures $\left(<200{ }^{\circ} \mathrm{C}\right)$ and fluid salinities below $5 \mathrm{wt} \% \mathrm{NaCl}$ eq. (Kelly and Rye 1979; Bussink 1984; Polya et al. 2000; Jaques and Pascal 2017; Lecumberri-Sanchez et al. 2017). Geothermometry based on arsenopyrite compositions, Tiin-quartz, and muscovite-tourmaline B-isotope exchange (Jaques and Pascal 2017; Codeço et al. 2017, 2019) indicates significantly higher temperatures ranging from 420 to $490{ }^{\circ} \mathrm{C}$ for the early stages of hydrothermal alteration and vein formation and about $250^{\circ} \mathrm{C}$ for late-stage mineralization hosted in cross-cutting fault zones.

The major-element composition of Panasqueira tourmaline has been studied by several workers (Neiva et al. 2007; Codeço et al. 2017; Launay et al. 2018). Tourmaline has intermediate schorl-dravite compositions with significant excess $\mathrm{Al}$ in octahedral $\mathrm{Y}$-sites (up to $0.9 \mathrm{apfu}$ ), variable $\mathrm{X}$-site vacancies ( 0.1 to $0.6 \mathrm{apfu}$ ), and relatively high $\mathrm{F}$ contents (up to $0.7 \mathrm{apfu}$ ). Tourmaline grains are typically zoned and show significant increases in $\mathrm{Fe}, \mathrm{F}$, and $\mathrm{Na}$ and decreases in $\mathrm{Mg}, \mathrm{Ca}$, and $\mathrm{Al}$ from core to rim. Codeço et al. (2017) noted a trend of decreasing $\mathrm{Al}$ and increasing $\mathrm{Mg} / \mathrm{Fe}$ with distance from the vein contact, which was attributed to the influence of the host schists, where tourmaline formed at the expense of the chlorite-biotite-rich protoliths. Codeço et al. (2019) presented major-element data of white mica and documented a range in compositions from muscovite towards the celadonite and alumino-celadonite end members. The main chemical variations in terms of major elements are in the $\mathrm{Fe} / \mathrm{Mg}$ ratio and in the $\mathrm{Al}$ and $\mathrm{F}$ contents. Mica in the greisen has the highest $\mathrm{Fe} / \mathrm{Mg}$ ratios (up to 10), mica from altered host rocks (tourmaline-quartz-mica zone) has the lowest values $(0.5-1)$, and vein-selvage micas have intermediate values. The composition of mica from the greisen, most vein selvages, and altered wall rocks overlap in terms of $\mathrm{Al}$ and $\mathrm{F}$, the exception being mica in topaz-rich selvages, which has the highest $\mathrm{F}$ and lowest $\mathrm{Al}$ contents (1-1 .5 apfu $\mathrm{F}$ and $1.5-2$ apfu $\mathrm{Al})$.

\section{Samples}

\section{Whole-rock samples}

Samples for whole-rock analysis were collected from three drill cores from underground galleries (D1602, M1609, and M1610) and four drill cores from the surface (SCB-1, SCB-2, SPS-1, and SMN-1). Their locations are shown in Figure S1 of the Electronic Supplementary Material 1 (ESM 1), and further details are in ESM2 (Table S1) and Codeço et al. (2020) (Table D1). Additionally, two outcrop samples (CXG1-2, CXG-2), located respectively at 5.5 and $10.5 \mathrm{~km}$ distance from the deposit, were taken as examples of the regional metasediments (ESM 1; Codeço et al. 2020, Table D2). The drill cores SMN-1, SPS-1, and SCB-2, located N and NE of the current underground workings, contain unaltered metasediments consisting of light green-colored phyllite and schist, intercalated with quartzite and metagreywacke layers (Fig. 2a, b). The main minerals are white mica, biotite, chlorite, and quartz. The unaltered schist in the drill cores is very similar to samples of the country rocks collected from outcrops outside of the mine area, whose main mineralogy comprises quartz, white mica, and minor biotite, with accessory zircon and feldspar.

Drill core SCB2 intersects the Panasqueira granite at a distance of about $800 \mathrm{~m}$ NE from the known cupola and $315 \mathrm{~m}$ below the surface. The contact zone consists of pelitic, granoblastic hornfels with a thickness of about $1 \mathrm{~m}$, composed of quartz, white mica, biotite, and feldspars with accessory tourmaline, cassiterite, sulfides, and chlorite (Fig. 2c). The hornfels shows a gradational transition downward through greisen, from 316 to $327 \mathrm{~m}$ depth, into granite (Fig. 2d). The coarse-grained, two-mica granite has white mica dominating over biotite and also contains albite, K-feldspar, and quartz (Fig. 2e), as well as accessory zircon. The granite is altered in some domains by muscovitization of feldspars and chloritization of biotite (Fig. 2f).

Petrographic studies of the metasediments in drill cores from underground galleries confirm that tourmalinization (tourmaline-quartz-muscovite zone) only occurs around quartz veins and veinlets. The abundance of tourmaline increases towards veins and veinlets (Fig. 2g), and the thickness of the tourmaline-muscovite zone is a function of the vein size and vein density (Fig. 2h). Samples more distal to the veins 
lack tourmaline and contain predominantly quartz, biotite, chlorite, and white mica (Fig. 2i).

\section{Mineral samples}

Samples for LA-ICP-MS analysis were chosen from a larger sample set that was described and analyzed for major-element chemical and boron isotopes in tourmaline and white mica by Codeço et al. (2017, 2019). The samples containing mica and tourmaline represent different types of vein selvages, wall rock, greisen, and fault zones, and their locations are given in ESM 1-Figure S3, ESM2-Table S1, and Codeço et al. (2020) (Table D3).

\section{Veins and vein selvages}

In the veins, white mica is the second-most abundant silicate mineral after quartz. There is considerable variability in the vein selvages, but most veins are bordered by mica-rich selvages (MRS) (Fig. 3a). Less common are veins with micapoor selvages (MPS) and topaz-rich selvages (TRS). The MRS are several centimeters thick and consist of white mica, quartz, arsenopyrite, wolframite \pm chalcopyrite \pm pyrite \pm sphalerite and locally also tourmaline, topaz, and apatite (Figs. 3a-d). At the vein contact, mica typically forms finegrained (FG) flakes intergrown with quartz and minor tourmaline. A coarse-grained (CG) generation of white mica typically develops towards the center of the vein and is commonly intergrown with wolframite (Fig. 3b, e). The MPS are thin layers $(<<1 \mathrm{~cm})$ at the edge of the veins consisting of quartz, topaz, tourmaline, and variable amounts of sulfide minerals (Fig. 4a). The TRS are one to several centimeter-thick layers at vein margins that contain light-green, massive topaz aggregates, partly replaced by secondary fine-grained white mica (Codeço et al. 2019). Unfortunately, the mica in TRS samples is too fine grained for LA-ICP-MS measurements. Tourmaline is not common in the veins, but it locally forms grain aggregates at the selvages or overgrowths on disrupted fragments of wall rock enclosed in the vein quartz (Fig. 3a, b). Tourmaline commonly shows optical and chemical zoning (see Fig. 3d and Codeço et al. 2017, for details).

\section{Wall rock alteration zones}

White mica in the wall rock alteration zones typically forms fine-grained $(<1 \mathrm{~mm})$ flakes associated with tourmaline, quartz, and minor Ti-(Fe)-oxides (Fig. 3f, g). Mica is less common in the alteration zones of the coarser-grained spotted schists, these zones being instead dominated by tourmaline with minor quartz. Tourmaline in the alteration zones can reach up to 70 modal $\%$ of the rock. It is typically fine grained, $<0.1$ to $0.3 \mathrm{~mm}$ (Fig. 3f), but the grain size is larger in the spotted schist ( 0.1 to $1 \mathrm{~mm}$ ).
Cross-cutting fault zones, late vugs, and greisen

Localities with more intense alteration related to syn- to postmineralization faulting or fault reactivation (Fig. 3a, g) typically contain coarser-grained tourmaline and mica, as well as a more complex accessory mineral assemblages with $\mathrm{Ti}-(\mathrm{Fe}, \mathrm{W}, \mathrm{Sn}, \mathrm{Cr}, \mathrm{Sr}, \mathrm{V})$-oxide minerals. These zones commonly contain veinlets and vugs filled by apatite and variable amounts of sulfide minerals (Fig. $3 a)$. Zoned tourmaline crystals are also present as needles in late vugs ( \pm carbonates \pm quartz) at the vein margins, i.e., post-mineralization cracks or fractures (Fig. 4b). Mica is absent in these late vugs.

The greisen zone contains white mica as a major phase, where it is fine- to medium-grained (up to $2-3 \mathrm{~mm}$ ) and shows compositional zonation, which is more prominent along cleavage planes and rims (Fig. 4c). Tourmaline was not found in any samples of the greisen in our study or in previous publications.

\section{Methods}

\section{Whole-rock geochemistry}

All samples were crushed and subsequently powdered in an agate mill to a grain size of less than $62 \mu \mathrm{m}$. Majorelement oxides $\left(\mathrm{SiO}_{2}, \mathrm{TiO}_{2}, \mathrm{Al}_{2} \mathrm{O}_{3}, \mathrm{Fe}_{2} \mathrm{O}_{3}, \mathrm{MnO}, \mathrm{MgO}\right.$, $\left.\mathrm{CaO}, \mathrm{Na}_{2} \mathrm{O}, \mathrm{K}_{2} \mathrm{O}, \mathrm{P}_{2} \mathrm{O}_{5}\right)$ and trace elements $(\mathrm{Ba}, \mathrm{Cr}$, $\mathrm{Ga}, \mathrm{Nb}, \mathrm{Ni}, \mathrm{Rb}, \mathrm{Sr}, \mathrm{V}, \mathrm{Y}, \mathrm{Zn}, \mathrm{Zr}$ ) were analyzed on fused disks using a PANalytical Axios Advanced wavelength-dispersive X-ray fluorescence spectrometer (XRF) at GFZ Potsdam. A Dionex ICS-1100 Ion Chromatograph from Thermo Fischer was used to analyze fluoride (F-) anions in aqueous solutions. The separation process is based on the distribution of the substance into a mobile fluid phase and a solid stationary phase. Sulfur was determined using an Eltra CS 2000 element analyzer. Samples were quantified using calibration curves generated from 105 reference materials.

Additional trace elements (As, $\mathrm{Be}, \mathrm{Bi}, \mathrm{Cd}, \mathrm{Co}, \mathrm{Cs}, \mathrm{Cu}, \mathrm{Ge}$, $\mathrm{Mo}, \mathrm{Pb}, \mathrm{REE}, \mathrm{Sb}, \mathrm{Sc}, \mathrm{Sn}, \mathrm{Th}, \mathrm{Tl}, \mathrm{U}, \mathrm{W}$ ) were analyzed in a subset of samples by inductively coupled plasma mass spectrometry (ICP-MS) at GFZ Potsdam, using a HR-ICP-MS Thermo Element 2XR. A 125-mg sample material was digested in $\mathrm{HF}$ and aqua regia following Pretorius et al. (2006) and Romer and Hahne (2010). The internal standard indium was added to the solutions to monitor for drift. The full dataset, including major-, minor-, and trace-element analyses from this study, is given by Codeço et al. (2020) (Table D4). In addition to these data, we also included published data from the granite and greisen from Pinto (2014). 

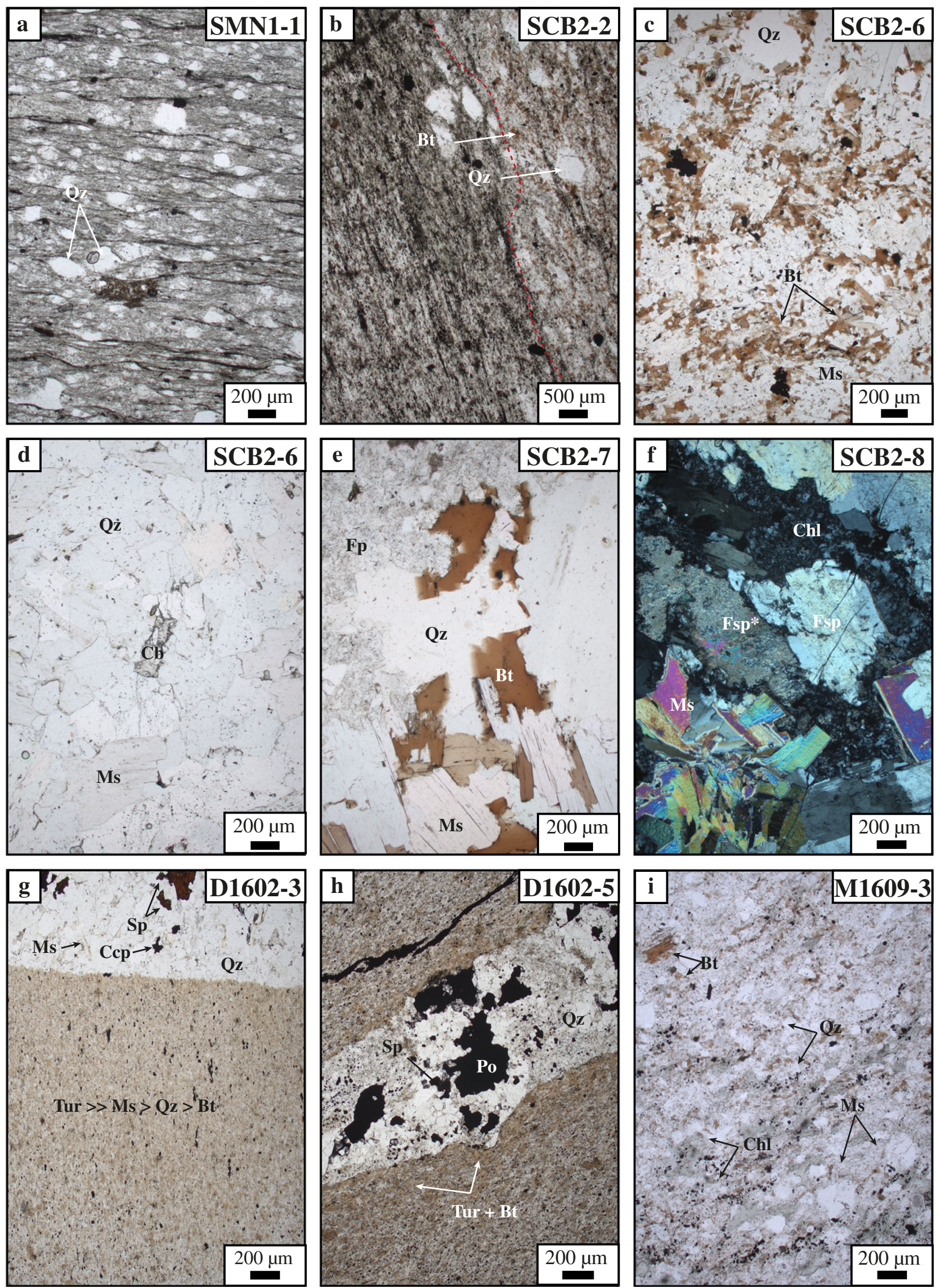
Fig. 2 Photomicrographs (plane polarized except for i) of samples from drill cores showing $\mathbf{a}$ unaltered greywacke; $\mathbf{b}$ alternation of pelitic layers (left) with greywacke layers from unaltered metasediments; $\mathbf{c}$ pelitic hornfels resulting from contact metamorphism; $\mathbf{d}$ greisen near the contact with the hornfels; e coarse-grained two-mica granite; $\mathbf{f}$ altered granite with muscovitization of feldspars and chloritization of biotite (cross polarized); g contact between tourmalinized fine-grained metapelite and a quartzsulfide veinlet; $\mathbf{h}$ quartz-sulfide veinlet in hydrothermally altered metapelite, tourmalinized at the contact; $\mathbf{i}$ unaltered muscovite-quartzbiotite-chlorite-metapelite. Mineral abbreviations: Bt biotite, $\mathrm{Cb}$ carbonates, Ccp chalcopyrite, Chl chlorite, K-Fsp K-feldspar, Ab albite, Fsp* altered feldspar, Ms muscovite/white mica, Qz quartz, Po pyrrhotite

\section{Laser ablation ICP-MS}

For in situ analyses of white mica and tourmaline, 120- $\mu$ mthick polished sections from 10 samples (see ESM 1, Table S1) were prepared from the same billets used for microprobe and SIMS analyses in Codeço et al. (2017, 2019). Concentrations of ${ }^{7} \mathrm{Li},{ }^{11} \mathrm{~B},{ }^{23} \mathrm{Na},{ }^{24} \mathrm{Mg},{ }^{27} \mathrm{Al},{ }^{29} \mathrm{Si},{ }^{35} \mathrm{Cl},{ }^{39} \mathrm{~K}$, ${ }^{47} \mathrm{Ti},{ }^{51} \mathrm{~V},{ }^{55} \mathrm{Mn},{ }^{57} \mathrm{Fe},{ }^{63} \mathrm{Cu},{ }^{66} \mathrm{Zn},{ }^{85} \mathrm{Rb},{ }^{88} \mathrm{Sr},{ }^{89} \mathrm{Y},{ }^{90} \mathrm{Zr},{ }^{118} \mathrm{Sn}$, ${ }^{133} \mathrm{Cs},{ }^{137} \mathrm{Ba},{ }^{153} \mathrm{Eu},{ }^{181} \mathrm{Ta},{ }^{182} \mathrm{~W},{ }^{205} \mathrm{Tl}$, and ${ }^{208} \mathrm{~Pb}$ in mica and tourmaline grains were determined using a NewWave 213-nm Nd-YAG laser, coupled to a Thermo-Finnigan iCAP Qc quadrupole ICP-MS, at the Earth and Planetary Sciences Department, McGill University. Except for grains $<40 \mu \mathrm{m}$ in size, which were mostly tourmaline, line scan mode was used to minimize the analysis of subsurface inclusions. The analytical conditions were 9 to $10 \mathrm{~J} / \mathrm{cm}^{2}$ fluence, $10-\mathrm{Hz}$ laser pulse frequency, 20- $\mu \mathrm{m}$ line width, $5-\mu \mathrm{m} / \mathrm{s}$ line scan speed, 30-s warmup, approximately 40-s ablation time, and 20-s washout. The ablated material was transported to the ICP-MS in an $800 \mathrm{~mL} /$ min He flow and mixed with Ar prior to injection into the plasma. Analyses of the unknowns were bracketed with analyses of reference NIST SRM 610 (glass). Also, at the beginning and end of each session, muscovite 98973, dravite 108796, schorl 112566 (Dyar et al. 2001), an in-house tourmaline (UoB), as well as BGR-2G and GSD-1G reference materials (GEOREM database-Jochum et al. (2016)) were measured to assess analytical quality.

The raw data were processed using the Iolite software v. 2.5 (Paton et al. 2011). The limits of detection (LOD) and uncertainties of each element and mineral are reported in Codeço et al. (2020) (Tables D7 and D8). The abundance of the major elements ( $\mathrm{Na}, \mathrm{K}, \mathrm{Mg}, \mathrm{Fe}, \mathrm{Ti}, \mathrm{Al}, \mathrm{Mn}, \mathrm{Si}$ ) was used to normalize the collected dataset to 15 cations at the $\mathrm{Y}, \mathrm{Z}$, and $\mathrm{T}$ sites (for tourmaline) and 22 total charges (for white mica) and thereby correct for differences in ablation behavior between the samples and NIST-SRM 610. This method avoids the need for an externally determined reference element. Comparison with major elements determined by electron microprobe from Codeço et al. $(2017,2019)$ shows good agreement. Laser ablation analyses are provided in Codeço et al. (2020) (Tables D5 and D6).

\section{Principal component analysis}

Principal component analysis (PCA) is a multivariate statistical technique that identifies compositional vectors in a dataset by transforming the initial variables, e.g., element concentrations into a set of principal components (PCs). These PCs are defined as orthogonal linear combinations of the initial variables that align with the maximum variance in the dataset, with PC1 representing the most variance (Pawlowsky-Glahn et al. 2015). Eigenvalues and eigenvectors are used to characterize each PC. The eigenvalues represent the contribution of each principal component to the overall variance of the original data, while the eigenvectors represent the correlations between the initial data and the principal components (Pawlowsky-Glahn et al. 2015). The PCs with low eigenvalues are assumed to be dominated by "noise," and when these are discarded, the dimensionality of the dataset is reduced, which facilitates interpretations of datasets with a large number of elements.

Geochemical datasets typically contain "censored data," i.e., missing values corresponding to analyses below detection limit (DL) or "structural zeros," i.e., components not measured (Van Den Boogaart et al. 2006). These introduce limitations for the application of multivariate statistical methods that require complete datasets. For the PCA of the whole-rock data, we used all samples having the full suite of elements analyzed and added the analyses from Pinto (2014) that contained no censored data. Laser ablation ICP-MS always contain censored data because the small grain size of tourmaline forced laser ablation analysis to be conducted with a smaller beam size $(20 \mu \mathrm{m})$, leading to relatively high detection limits for some trace elements. One solution to censored data is to exclude the data or to substitute the missing values by the DL, DL/ $\sqrt{2}$, or zero (Croghan and Egeghy 2003; Verbovšek 2011), but this can introduce bias (Dupuis and Beaudoin 2011; Makvandi et al. 2016a). Alternatively, censored data can be estimated by statistical methods (Aitchison 1982; Filzmoser et al. 2009; Hron et al. 2010), and the k-nearest neighbor $(\mathrm{kNN})$ approach has been suggested to be the optimal imputation method for compositional datasets (Hron et al. 2010; Grunsky et al. 2013; Makvandi et al. 2016a, 2016b, 2019; Huang et al. 2019). Applying this method can have the drawback of neglecting the constraint that data fall below the DL, unless the method further enforces that the imputed values stay below the DL.

With respect to our datasets, the application of these different methods to pre-process censored data has only a minor influence on the PCA results. For this paper, we decided to substitute values below DL by $\mathrm{DL} / \sqrt{2}$ because the $\mathrm{kNN}$ imputation method (calculated with robCompositions package in $\mathrm{R})$ resulted in values more than three times the DL, which clearly overestimated the low-concentration trace elements. We use the DL determined for the individual measurement 


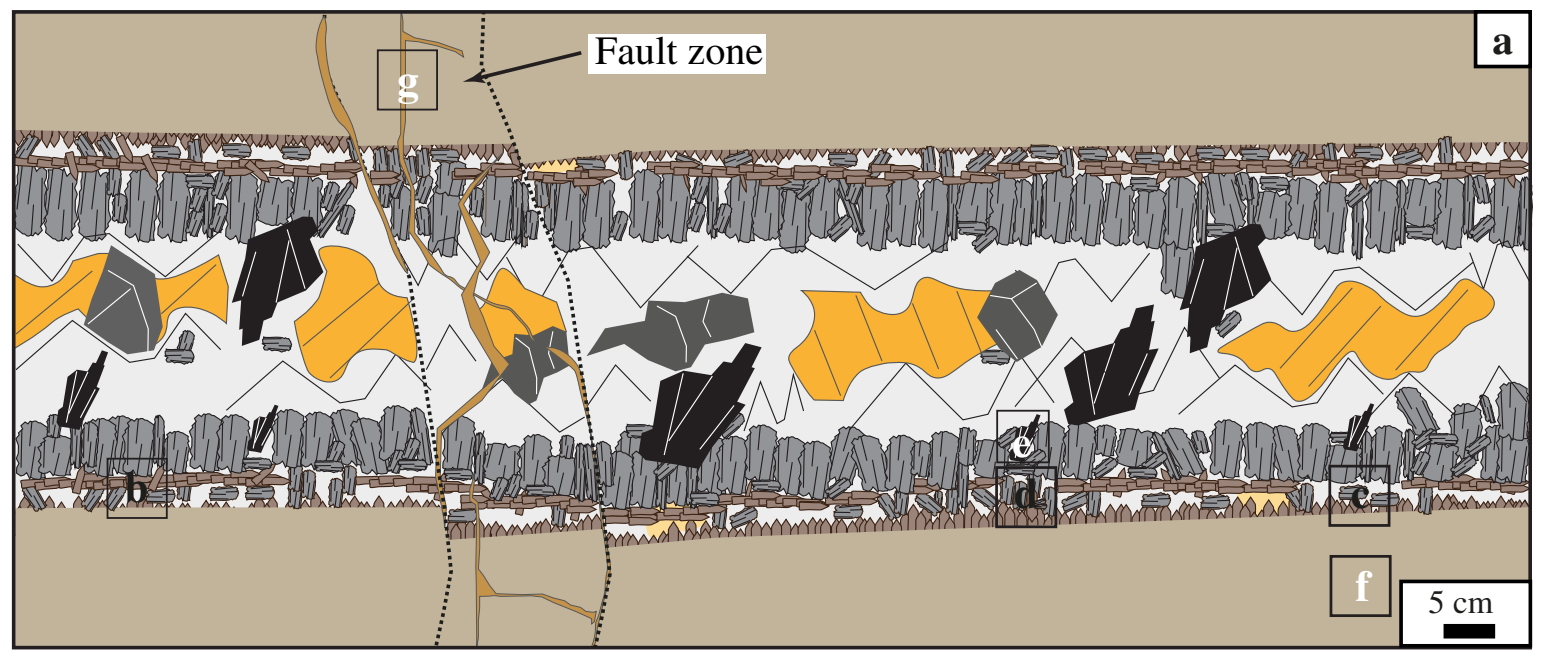

\begin{tabular}{|c|c|c|c|}
\hline$>$ Quartz $(\mathrm{Qz})$ & Arsenopyrite & $\Delta$ & Sphalerite \\
\hline Tourmaline (Tur) & If Wolframite & ए & Tur-Qz-Ms alteration zone \\
\hline White mica (Ms) & $\approx$ Chalcopyrite & 2 & Late-fault zone (with apatite-sulfide veinlets) \\
\hline
\end{tabular}
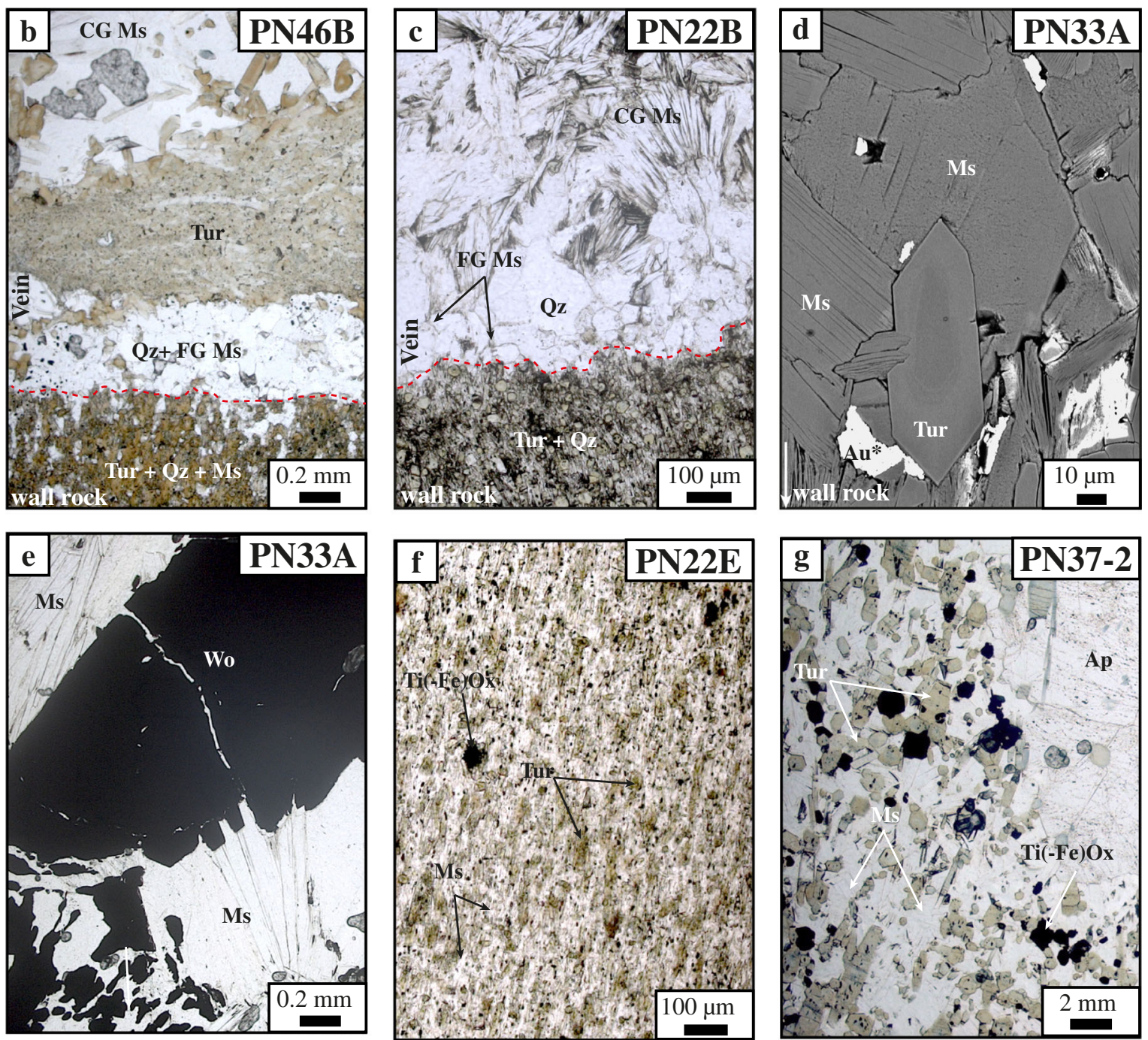
Fig. 3 a Schematic cross section of a typical mica-rich selvage vein, including the tourmaline-mica-quartz alteration zone and a late fault zone. b-g Examples of white mica and tourmaline occurrences in the MRS type veins: b photomicrograph (plane polarized) of the contact between tourmalinized wall rocks and MRS showing tourmaline aggregate (slivers) within the vein; c photomicrograph (plane polarized) of the contact between tourmalinized wall rocks and a mica-rich selvage (MRS); $\mathbf{d}$ BSE image of the contact between wall rocks and vein showing mica intergrown with tourmaline; e photomicrograph (plane polarized) of feathery mica intergrown with wolframite in MRS; f photomicrograph (plane polarized) of fine-grained mica and tourmaline in the altered wall rock schist; $\mathrm{g}$ photomicrograph (plane polarized) of coarse-grained tourmaline, mica, and apatite with $\mathrm{Fe}-\mathrm{Ti}$ oxides in a fault zone. Mineral abbreviations: Ms muscovite/white mica, Qz quartz, Tur tourmaline, Wo wolframite, Ap apatite, Ti(-Fe) Ox Ti-Fe oxides. FG fine grained, $\mathrm{CG}$ coarse grained. $\mathrm{Au}^{*}$ refers to gold coating from SIMS measurements

wherever possible or, alternatively, the median DL value of the dataset for the respective element, when individual DLs are not available. Data were then transformed using the centered log-ratio (CLR) method in which each variable is divided by the geometric mean of all values and then log normalized (Filzmoser et al. 2009). The PCA calculations and graphical results were made with the ioGAS ${ }^{\mathrm{TM}}$ software (REFLEX 2019). The imputation methods testing and the corresponding PCA results are described in full in the ESM 3.

\section{Results}

\section{Whole-rock compositions}

Both the tourmaline-muscovite-quartz alteration zone and unaltered metasediments show a wide compositional range for most major elements as a consequence of the varying proportions of sandstone-shale intervals in the protolith. Overall, the compositions of the unaltered schist and granite from our study compare well with analyses from the literature (Bussink 1984; Neiva 1987; Ugidos et al. 2010; Villaseca et al. 2014), showing that the metasediments and intrusion at Panasqueira have compositions typical for this region. The majorand rare earth element (REE) contents of unaltered and altered metasediments overlap completely (Fig. 5a). REE patterns show relatively high middle- and heavyREE contents ( $\mathrm{Sm}, \mathrm{Eu}, \mathrm{Gd}, \mathrm{Yb}, \mathrm{Lu}$ ) compared to the light REE. Since neither major elements nor REE are useful indicators of the alteration, we mainly focus on other minor- and trace-element contents. The element concentrations were normalized to those of the average upper continental crust (Rudnick and Gao 2014) (Fig. $5 \mathrm{~b})$. The altered schists show enrichments in As, Sn, $\mathrm{Cd}, \mathrm{Cs}, \mathrm{Li}, \mathrm{W}, \mathrm{F}, \mathrm{Bi}, \mathrm{Cu}, \mathrm{Rb}, \mathrm{Zn}, \mathrm{Tl}$, and $\mathrm{Be}$ compared to the unaltered metasediments, which is in good agreement with earlier findings of Bussink (1984). Also, most of these same elements are enriched in the greisen relative to the unaltered granite (Fig. 5c). mica-poor selvage type
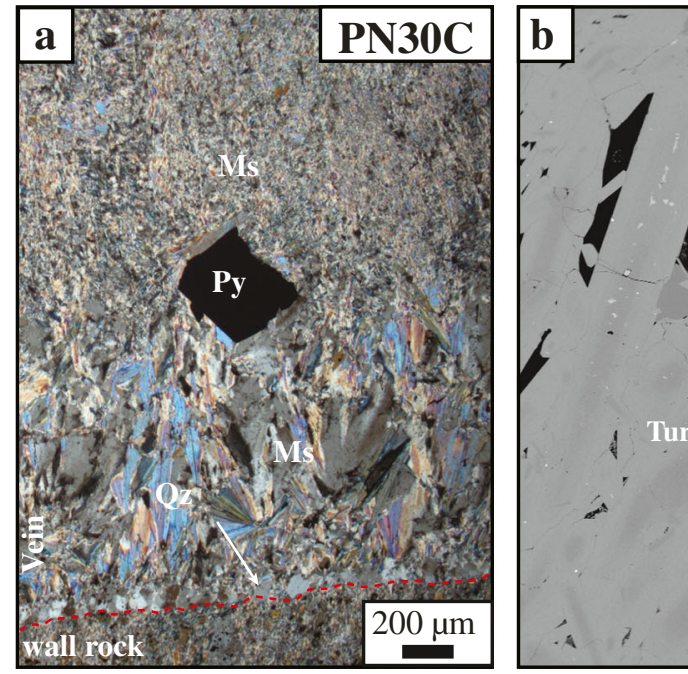

Fig. 4 Examples of white mica and tourmaline in the Panasqueira mine. a Photomicrograph (cross polarized) of the contact between the tourmalinized wall rocks and a mica-poor selvage (MPS), comprising a coarse-grained layer of quartz and mica and a domain of fine-grained late vugs
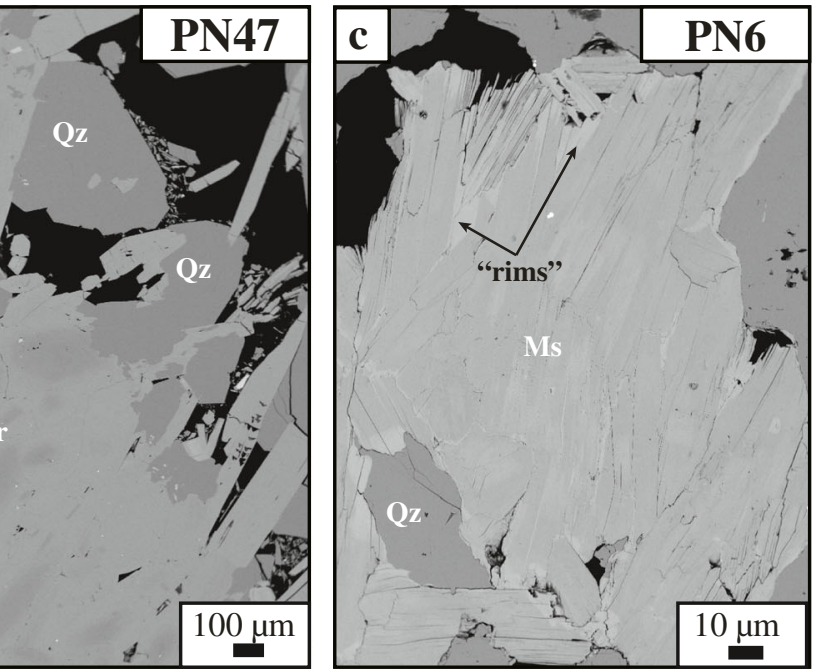

white mica replacement after an unknown phase and pyrite. b Backscatter electrons (BSE) image of tourmaline and quartz from a latestage vug. $\mathbf{c}$ BSE image of zoned mica in the greisen. Mineral abbreviations: Ms muscovite/white mica, Qz quartz, Tur tourmaline, Py pyrite 
Fig. 5 a Rare earth element contents of altered and unaltered metasediments. b Multi-element plot of altered and unaltered metasediments. c Multi-element plot of granite and greisen. All data are normalized to the upper continental crust (Rudnick and Gao 2014) and plotted in a sequence from left to right according to their decreasing normalized abundance in the altered rocks. Data sources: ${ }^{(1)}$ Pinto (2014),

${ }^{(2)}$ Ugidos et al. (2010),

${ }^{(3)}$ Villaseca et al. (2014),

${ }^{(4)}$ Bussink (1984), and

${ }^{(5)}$ Neiva (1987)
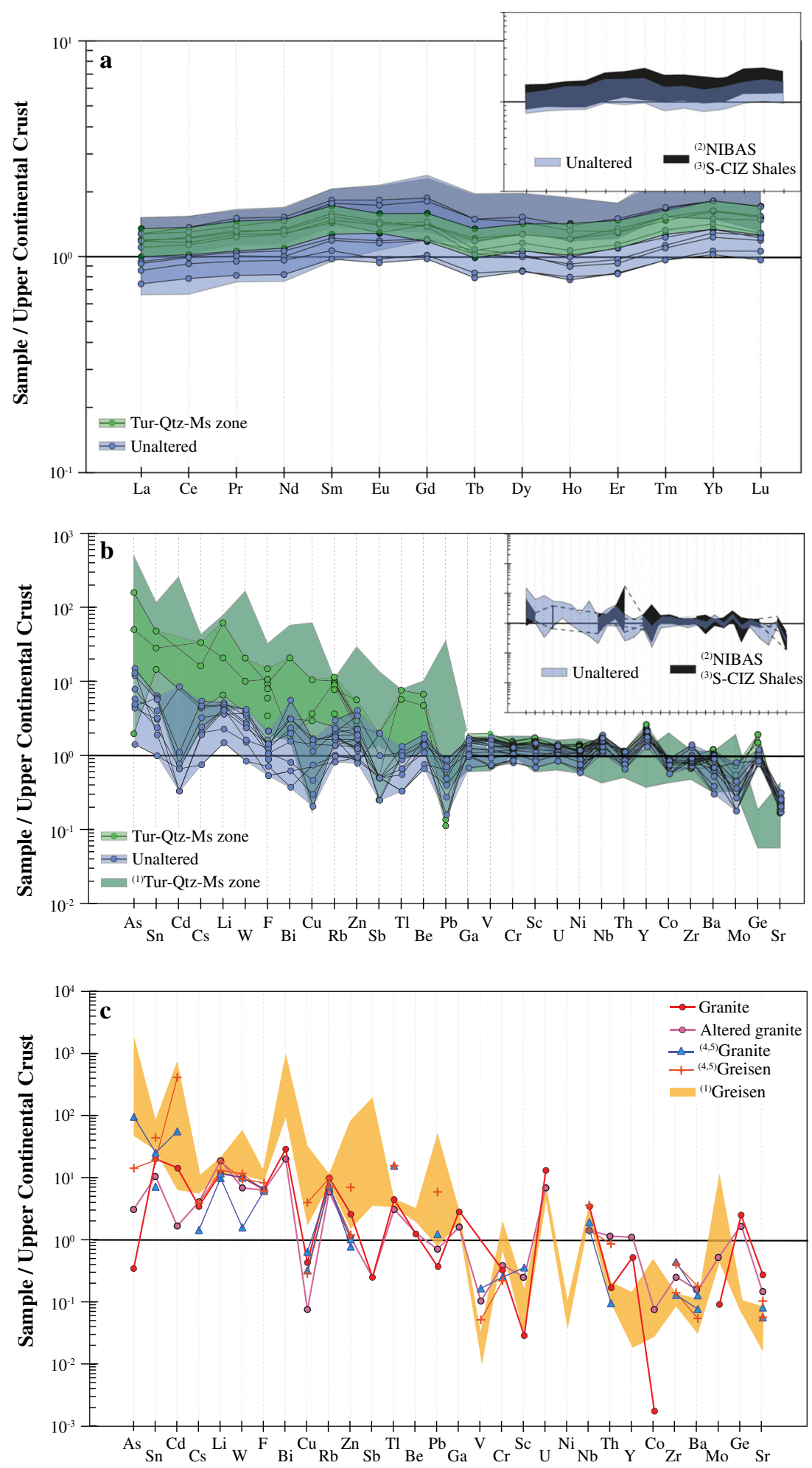

\section{Trace-element contents of white mica and tourmaline}

For the description of the trace-element results, we focus on the elements that are consistently enriched in the altered rocks, namely $\mathrm{Sn}, \mathrm{W}, \mathrm{Cu}, \mathrm{Zn}, \mathrm{Cs}, \mathrm{Li}$, and $\mathrm{Rb}$, as well as some that were unaffected by alteration, e.g., $\mathrm{Mg}, \mathrm{V}$, and Sr. Some elements that exhibited important variations in the whole-rock data either could not be analyzed by LA-ICP-MS (F) or were below detection limits ( $\mathrm{As}, \mathrm{Cd}, \mathrm{Bi}, \mathrm{Sb}$ ). Tantalum was not analyzed in the whole rock, but we measured Ta by LA- 
ICP-MS in addition to $\mathrm{Nb}$ because the $\mathrm{Nb} / \mathrm{Ta}$ ratio is useful as a marker of magmatic-hydrothermal processes (Ballouard et al. 2016). Chlorine was analyzed but not detected by LAICP-MS measurements and, therefore, excluded from the dataset.

\section{White mica}

White mica compositions show positive correlations for a number of element pairs with different slopes in different samples, in Li vs. Mg (Fig. 6a), Nb vs. Ta (Fig. 6b), and Cs vs. Rb (Fig. 6c). Strontium and $\mathrm{V}$ show a positive correlation in general, with highest $\mathrm{V} / \mathrm{Sr}$ ratios in the fault (median $=30.2$ ) and wall rock alteration zones $($ median $=6.4)$ and the lowest $\mathrm{V} / \mathrm{Sr}$ ratios in micas from the greisen (median $=0.01$ ) (Fig. 6d). The FG mica from MRS and MPS has higher $\mathrm{V}$ and $\mathrm{Sr}$ contents than CG mica in the same samples (Fig. 6d). Tin and W contents show an overall negative correlation, with the highest $\mathrm{W} / \mathrm{Sn}$ ratio in greisen mica (median $=0.7$ ) and the lowest $\mathrm{W} / \mathrm{Sn}$ in mica within the fault zone (median = 0.08) (Fig. 6e). Copper and $\mathrm{Zn}$ are both highly variable and do not correlate with each other (Fig. 6f).

Mica from the greisen sample shows the most distinctive composition compared with other settings and generally has low $\mathrm{Mg}$, high $\mathrm{Ta}$ and $\mathrm{Nb}$ contents (up to 100 and $200 \mathrm{ppm}$, respectively) and high $\mathrm{W}$ and $\mathrm{Zn}$ (up to 120 and $150 \mathrm{ppm}$, resp.), partially overlapping with the MRS micas, but low Sn contents (70-170 ppm). The $\mathrm{Li}, \mathrm{Cs}, \mathrm{Rb}$, and $\mathrm{Cu}$ contents of greisen mica are variable and overlap with those of other settings. Some of this variability relates to compositional zoning, with mica rims having higher $\mathrm{Li}$ and $\mathrm{Sn}$, but lower $\mathrm{Cu}$ and $\mathrm{W}$ values relative to cores (Fig. 6 a, e, and f). In terms of Cs, Rb, $\mathrm{Ta}$, and $\mathrm{Nb}$, mica compositions form two distinctive clusters within individual grains (Fig. 6b, c), but this clustering cannot be related to growth zones.

Mica from the MRS shows distinct trace-element compositions, forming clusters in several of the binary plots. For example, sample PN46 stands out with high $\mathrm{Nb}$ and $\mathrm{Ta}$ contents that are comparable to the mica from the greisen. Sample PN22 has lower Li, Rb, and Zn contents compared to PN33 and PN46. Importantly, samples PN22 and PN33 contain two texturally distinctive mica varieties that could be analyzed separately, a fine-grained variety (FG) which occurs at the contact with the host rocks (Fig. 3a-c), and a coarse-grained variety $(\mathrm{CG})$ that is commonly associated with wolframite (see Fig. 3a-d). In general, the fine-grained mica ("FG" in Fig. 6) has lower $\mathrm{Rb}$ and $\mathrm{W}$ contents, but higher $\mathrm{Mg}, \mathrm{Sn}$, $\mathrm{Nb}, \mathrm{Ta}, \mathrm{Sr}$, and $\mathrm{V}$ than the coarser mica in these samples and in sample PN46, which has only CG mica.

White mica in wall rock alteration zones was generally too fine grained and intergrown with other phases to be measured by LA-ICP-MS. The single exception is sample PN30D, which yielded high $\mathrm{Li}$ and $\mathrm{V}$ contents compared with mica from vein selvages and greisen, but lower $\mathrm{W}$ and $\mathrm{Sn}$ contents. Wall rock mica from PN30D is similar to the FG mica from MRS in terms of $\mathrm{Mg}, \mathrm{Sr}, \mathrm{Nb}, \mathrm{Ta}, \mathrm{Cs}, \mathrm{Rb}$, and $\mathrm{Zn}$ contents. White mica from the fault zone (sample PN37-2) is distinctive from all others in terms of high $\mathrm{Li}, \mathrm{Mg}$, and $\mathrm{Sn}$ and low $\mathrm{Nb}$, Ta, and W contents. For the other elements shown, the faultzone mica and mica from vein selvages overlap.

\section{Tourmaline}

Tourmaline at Panasqueira is commonly zoned, with systematically higher $\mathrm{Fe} / \mathrm{Mg}$ ratios from core to rim (Codeço et al. 2017). Where grain size allowed, core and rim compositions of tourmaline were analyzed separately, and some trace elements reflect the zoning; rims have higher $\mathrm{Zn}$ and $\mathrm{Li}$ and lower $\mathrm{Sr}$ and $\mathrm{Mg}$ contents than cores (Fig. 7). However, because of the small grain size, most LA-ICP-MS analyses consist of mixtures between rim and core composition. Overall, the tourmaline crystals from all settings show overlapping compositions and only occasionally are clusters by sample or type evident (Fig. 7d, f). The only example of distinct compositions are cores of tourmaline from the fault zone and the late vugs (Fig. 7), which have the highest $\mathrm{Mg}$ and $\mathrm{Sr}$ and the lowest $\mathrm{Li}$ and $\mathrm{Zn}$ contents in the dataset (see Fig. 7a, d, f). The lithophile element pairs $\mathrm{Rb}-\mathrm{Cs}$ and $\mathrm{Nb}-\mathrm{Ta}$ show strong positive correlations with each other (Fig. 7c, d), as was noted in mica. The chalcophile $\mathrm{Zn}-\mathrm{Cu}$ element pair is not correlated, and $\mathrm{Cu}$ shows a random variation with no relationship to other elements, to crystal zoning, or to setting within the deposit (Fig. 7f). With few exceptions, both Sn and W concentrations are below 30 ppm. Like $\mathrm{Cu}$ and $\mathrm{Zn}$, the ore elements $\mathrm{Sn}$ and $\mathrm{W}$ neither show correlation with other elements in tourmaline nor is there a systematic difference in concentrations relative to crystal zoning or setting within the deposit (Fig. 7e).

\section{Discussion}

\section{Whole-rock chemistry}

The altered host rocks show enrichments in $\mathrm{W}, \mathrm{Sn}, \mathrm{Cu}$, and $\mathrm{Zn}$ as well as in $\mathrm{As}, \mathrm{F}, \mathrm{Li}, \mathrm{Rb}$, and $\mathrm{Cs}$ relative to the unaltered metasediments (Fig. 5). The principal component analysis (PCA) of all altered and unaltered schist samples was run with a set of 16 elements chosen to show different aspects of the element behavior (Fig. 8). We included two major elements (Fe, $\mathrm{Mg}$ ), ten elements that are most consistently enriched during alteration (W, Sn, Cu, Zn, F, Rb, Cs, Li, As, and Tl), and four elements that are observed to remain relatively unchanged during alteration (V, Sr, Ba, and Nb) (Fig. 5b). Three principal components (PCs) account for $82 \%$ of the total variance, with $52.9 \%$ for $\mathrm{PC} 1,22.2 \%$ for $\mathrm{PC} 2$, and $6.7 \%$ for $\mathrm{PC} 3$. PC1 separates unaltered and altered metasediment samples 

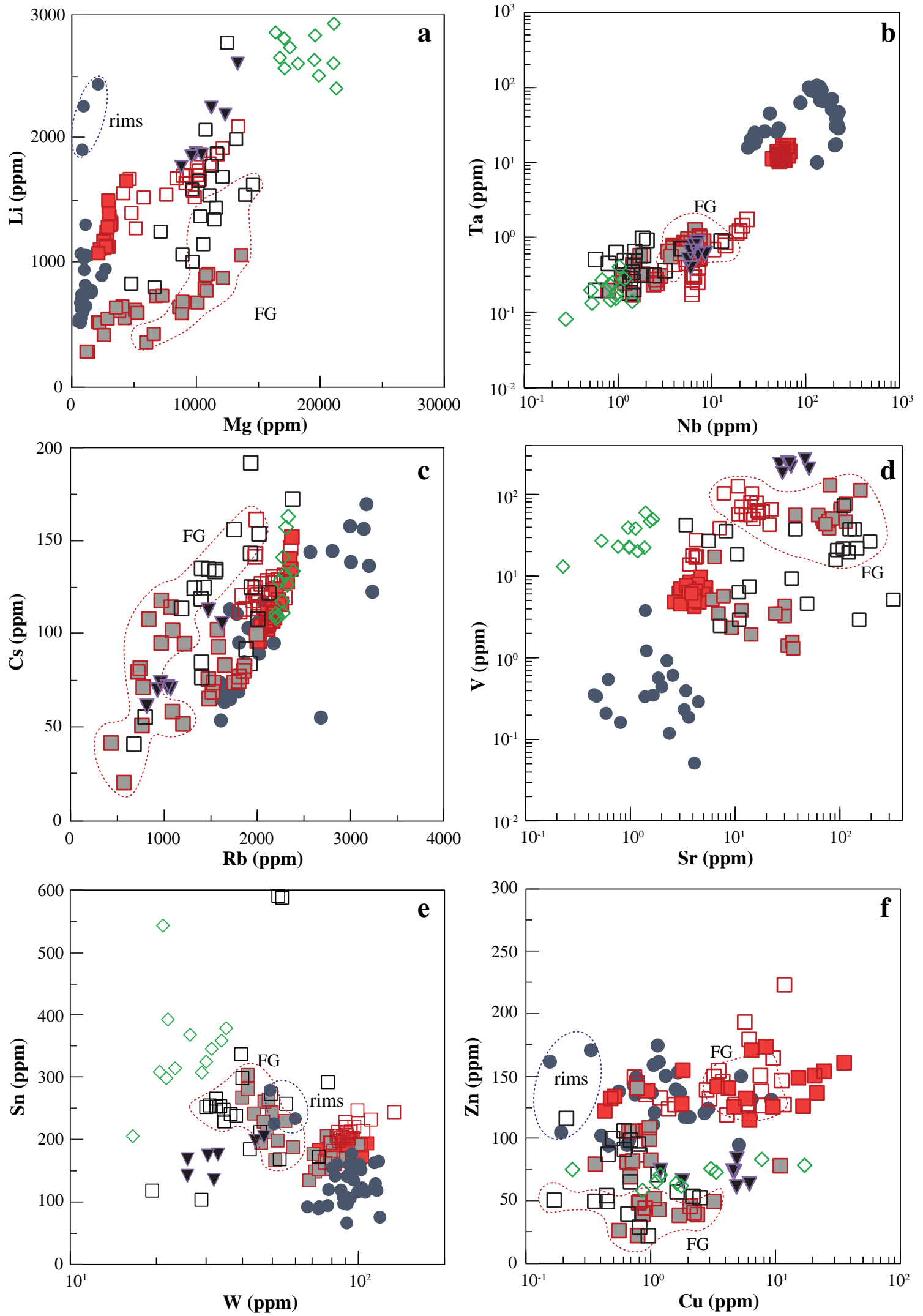

Greisen (PN6)

MRS (PN46B)

$\square$ MPS (PN30C)

$\diamond$ Fault (PN37-2)

MRS (PN22B)

MRS (PN33A)

$\nabla \mathrm{Wr}$ - dist (PN30D) 
4 Fig. 6 Variations of minor- and trace-element contents in white mica from different settings in the Panasqueira deposit. a Mg vs. Li. b Nb vs. Ta. c $\mathrm{Rb}$ vs. $\mathrm{Cs}$. d $\mathrm{Sr}$ vs. V. e W vs. $\mathrm{Sn}$. f $\mathrm{Cu}$ vs. $\mathrm{Zn}$. MRS mica-rich selvages, MPS mica-poor selvages, Wr-dist wall rock distal from the vein contact, FG fine-grained, rim rims or overgrowths in mica from the greisen

(Fig. 8a, c), and most of the ten alteration-related elements have positive loadings on $\mathrm{PC} 1$, whereas $\mathrm{Sr}, \mathrm{Ba}, \mathrm{Nb}$, and the major elements $\mathrm{Fe}$ and $\mathrm{Mg}$ load in the negative $\mathrm{PC} 1$ plane (Fig. 8a, b). PC2 seems to reflect the effects of relative distance of samples from the greisen cupola. The more distal samples have higher $\mathrm{Cu}$ and $\mathrm{Zn}$ and partially As (positive loadings in PC2), while proximal samples display higher Cs, $\mathrm{Rb}$, and $\mathrm{Tl}$ (negative loadings in PC2). There is also a weak distinction in PC2 for $\mathrm{F}$ and $\mathrm{Li}$ (higher in proximal samples) and for Sn and W (higher in distal samples). The proximal vs. distal differences make sense mineralogically, since samples close to the greisen are richer in mica, with vein selvages up to 3-cm thick (negative PC2 values), whereas the distal samples are associated with mineralized veins containing chalcopyrite, pyrite, arsenopyrite, cassiterite, wolframite, topaz, and sphalerite (positive PC2 values). Finally, PC3 only accounts for $6.7 \%$ of the variability and mainly separates the vectors that had loadings close to zero or weaker loadings in PC2 (i.e., Sn, W, Li, As, and F). It shows coupled behavior for As-W and $\mathrm{Sn}-\mathrm{F}$ pairs, which may reflect the petrographic observations that $\mathrm{Sn}$ mineralization is associated with F-rich phases (fluorite, fluorapatite, F-rich mica, and tourmaline) and wolframite with arsenopyrite.

The transition from unaltered to strongly altered metasediments next to the vein can be shown for single drill core profiles (M1610: Fig. 8e; filled circles in Fig. 8 a and c). The proximity to a mineralized vein on this plot increases downward, and the lower samples show higher scores in $\mathrm{PC} 1$, reflecting an increase in the alteration overprint. This increase begins at a distance of about $8 \mathrm{~m}$ from the vein (Fig. 8e) and marks the vertical extent of the alteration front in this profile.

\section{White mica and tourmaline}

The PCA results for white mica show a strong clustering by setting and sample, as seen in Fig. 6. Three components account for $86 \%$ of the total variance, with $50.5 \%$ in PC1, 25.6\% in PC2, and 9.4\% in PC3 (Fig. 9; see also ESM 3). High concentrations in $\mathrm{W}(\mathrm{Zn}), \mathrm{Ta}$, and $\mathrm{Nb}$ distinguish the greisen mica from mica in other settings. The fine-grained (FG) micas are distinct in terms of high $\mathrm{Mg}, \mathrm{Sr}, \mathrm{Ba}$, and $\mathrm{V}$ contents and in terms of high Sr contents for sample PN22 (Fig. 9b, d). The PCA results show that the FG mica has a chemical affinity with the host rocks, suggesting a stronger rock control in their composition. In contrast, the coarse-grained mica yields intermediate compositions between the FG mica and the greisen mica, suggesting greater influence of the hydrothermal fluid. Finally, mica from the fault zone stands out in terms of $\mathrm{Li}$ and $\mathrm{Sn}$ contents with strong positive loadings in PC2 and lower $\mathrm{W}, \mathrm{Ta}$, and $\mathrm{Nb}$ contents (Figs. 6 and 9a, b). The fault-zone mica also showed distinctly low B-isotopic values compared with mica from other settings $(-23$ to $-17 \%$; Codeço et al. 2019), which was interpreted as a consequence of cooling. Copper shows systematically negative correlation with Sn and is the only element with strong loadings in PC3, where it has a positive correlation with $\mathrm{Li}$, opposite to the negative correlation in PC2 (Fig. 9b, d).

For tourmaline, the lack of clear correlations between elements observed in the bivariate plots (Fig. 7) is also reflected in the PCA results (Fig. 10). In contrast to the whole-rock and mica data, four PCs are needed to explain the main chemical variations in tourmaline ( $80 \%$ of the total variance), with $43.8 \%$ for $\mathrm{PC} 1,17.1 \%$ for $\mathrm{PC} 2,11.1 \%$ for PC3, and $7.9 \%$ for PC4 (ESM 3: Fig. S5). Iron, Zn, Mg, V, Sr, Sn, Li, and $\mathrm{Cu}$ are coupled and load positively in $\mathrm{PC} 1$, whereas the elements $\mathrm{Cs}, \mathrm{Rb}, \mathrm{Ba}, \mathrm{W}, \mathrm{Nb}$, and Ta plot in the negative plane. Interestingly, the latter set of elements contains the ones where 25 to $37 \%$ of data are censored and were replaced by DL/ $/ 2$ values. PC2 (Fig. 10b) is characterized by positive loadings for $\mathrm{Rb}, \mathrm{Cs}$, and $\mathrm{Ba}$ and negative loadings for $\mathrm{Nb}$ and $\mathrm{Ta}$, indicating that these elements are not related in tourmaline, which is consistent with their geochemical behavior (LILE vs. HFSE). Tungsten also loads in the negative plane, but like $\mathrm{Cu}$, it is poorly represented by the first two components. We suggest that PC1 separates the "true" tourmaline composition (positive plane) from compositions likely affected by mineral inclusions (negative plane). Since Rb, Cs, Ta, Nb, Ba, and $\mathrm{W}$ have lower contents in tourmaline than in mica (see Figs. 6 and 7), these elements will be more sensitive to variance caused by inclusions of mica, rutile, and wolframite or fluid inclusions, which are visible in BSE images and under the microscope. If so, PC2 probably distinguishes between mica inclusions ( $\mathrm{Rb}, \mathrm{Cs}$, and $\mathrm{Ba}$ ) and rutile and/or wolframite $(\mathrm{Nb}$, $\mathrm{Ta}$, and $\mathrm{W}$ ) and fluid inclusions (which may contain both these element groups). In PC3, Fe, Zn, V, and Li load in the positive plane, while $\mathrm{Mg}$, $\mathrm{Sr}$, and $\mathrm{Sn}$ load in the negative plane. This division is related to zoning since tourmaline rims are consistently enriched in $\mathrm{Fe}$ and $\mathrm{Zn}$ and depleted in $\mathrm{Mg}$ and Sr relative to cores as described above. Even though the zoning is an important feature of tourmaline, it is only captured by PC3 due to the fact that the CLR treats the data such that the PCA results are not overly weighted by the major elements (i.e., $\mathrm{Mg}$ and $\mathrm{Fe}$ ). The relative importance of $\mathrm{W}$ and $\mathrm{Cu}$ increases from PC2 to PC4, with PC3 showing a positive correlation between the two and $\mathrm{PC} 4$ a negative one. This indicates that the variations of $\mathrm{W}$ and $\mathrm{Cu}$ are not systematic or are related to different processes, but our results cannot distinguish between these alternatives. 

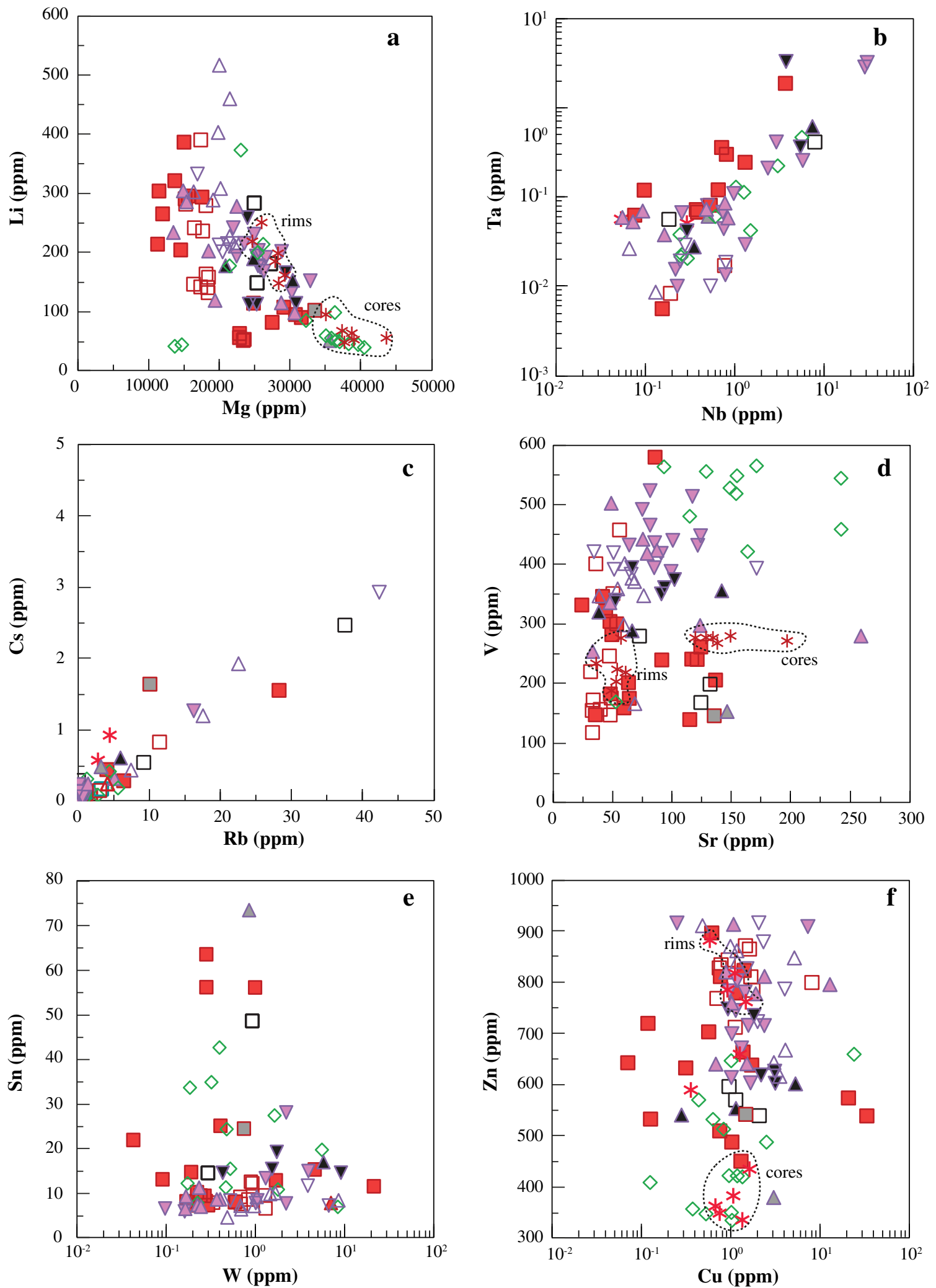

\begin{tabular}{|lllll|}
\hline$\square$ MRS (PN22B) & $\square$ MRS (PN46B) & $\square$ MRS (PN33A) & $\square$ MPS (PN30C) & $*$ Late-vugs \\
$\Delta$ Wr-prox (PN22B) & $\Delta$ Wr-prox (PN46B) & $\Delta$ Wr-prox (PN33A) & $\boldsymbol{\Delta}$ Wr-prox (PN30C) & $\diamond$ Fault \\
& $\nabla$ Wr-dist (PN46E) & $\nabla$ Wr-dist (PN33D) & $\boldsymbol{\nabla}$ Wr-dist (PN30D) & \\
\hline
\end{tabular}


Fig. 7 Variations of major-, minor- and trace-element contents in tourmaline from different settings in the Panasqueira deposit. a Mg vs. Li. b Nb vs. Ta. c Rb vs. Cs. d Sr vs. V. e W vs. Sn. f Cu vs. Zn. MRS mica-rich selvages, MPS mica-poor selvages, Wr-prox wall rock proximal to the vein-contact, Wr-dist wall rock distal from the vein contact; rims and cores of zoned grains in late vugs are outlined

Petrographic observations show that white mica and tourmaline are intergrown in many cases (see Fig. 3d), with sharp contacts, locally showing interpenetration, suggesting that they formed during the same event of hydrothermal alteration. Under equilibrium conditions, the composition of hydrothermal mica and tourmaline is controlled by partition coefficients of the elements between the mineral and fluid phase (van Hinsberg et al. 2010). We compared the traceelement compositions of such mineral pairs in contact to assess element partitioning between them (i.e., $D_{\text {element }}^{\text {tur/mica }}$ ). Correlation plots for selected trace elements (Fig. 11) show that $\mathrm{Li}, \mathrm{Rb}, \mathrm{Cs}, \mathrm{Tl}, \mathrm{W}$, and $\mathrm{Sn}$ preferentially partition into mica, with apparent $D^{\text {tur/mica }}$ values from 0.0001 to 0.5 , with sample medians from 0.001 to 0.08 . Copper, $\mathrm{Ta}$, and $\mathrm{Nb}$ show considerable scatter, but they also generally favor mica over tourmaline $\left(D^{\text {tur/mica }}=0.01\right.$ to 30 , median $=0.04$ to 0.61$)$, whereas $\mathrm{Sr}, \mathrm{V}$, and $\mathrm{Zn}$ partition preferentially into tourmaline
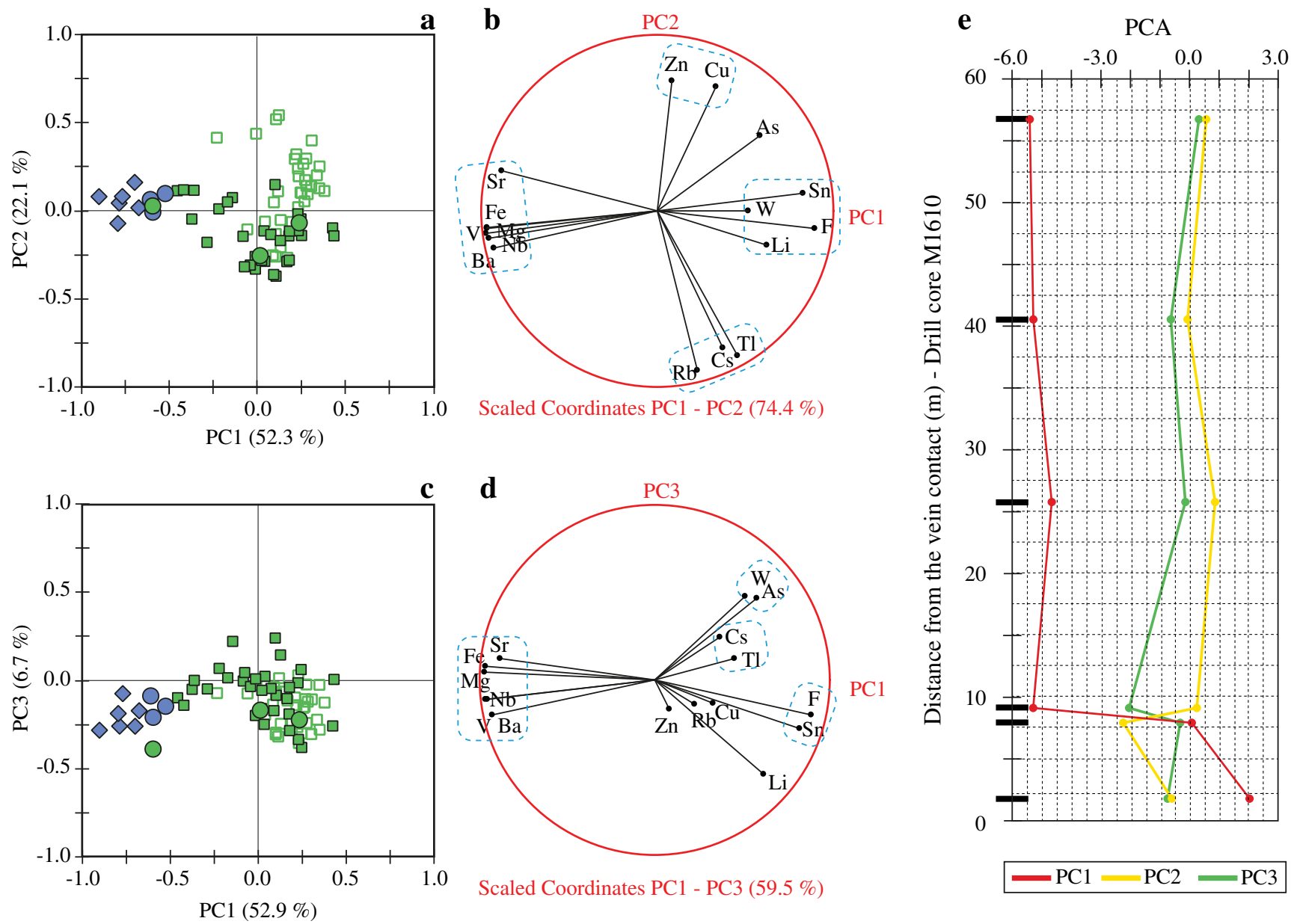

\begin{tabular}{|ll|}
\hline$\bigcirc$ & Unaltered metasediments (exploration drill cores) (this study) \\
$\bigcirc$ & Unaltered metasediments proximal (this study) \\
$\bigcirc$ & Altered metasediments proximal (this study) \\
$\square$ & Altered metasediments proximal (Pinto 2014) \\
$\square$ & Altered metasediments distal (Pinto 2014)
\end{tabular}

Fig. 8 Principal components analysis (PCA) of the altered and unaltered whole-rock compositions (a-d). a, c The log-transformed data plotted in PC1 vs. PC2 and PC1 vs. PC3 planes, respectively. b, d Element vectors (as variables) in the corresponding planes. The terms proximal and distal in the legend refer to distance from the greisen cupola. Dashed outlines in b and $\mathbf{d}$ highlight element clusters. e Vertical variations of PC1, PC2, and PC3 along drill core M1610 (drilled upward from a mine stope). Black rectangles correspond to the position of the samples studied. The kink in the PC1 curve at about $8 \mathrm{~m}$ marks the approximate boundary between altered and unaltered wall rocks 

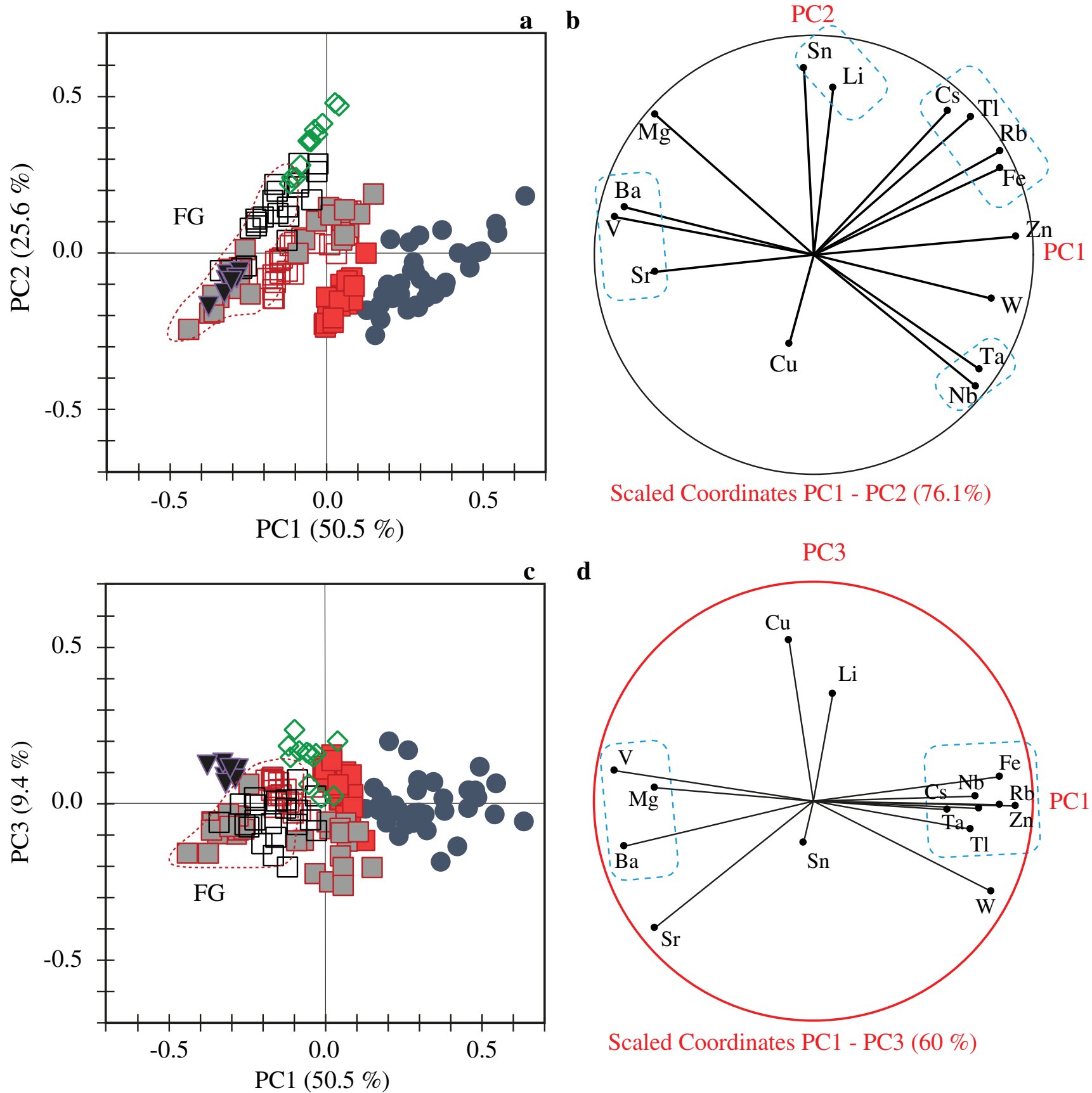

Scaled Coordinates PC1 - PC3 (60\%)

\begin{tabular}{|cclllll|}
\hline Greisen & $\square$ & MRS-type (PN22B) & $\square$ & MRS-type (PN33A) & $\nabla$ & WR-dist (PN30D) \\
& $\square$ & MRS-type (PN46B) & $\square$ & MPS-type (PN30C) & $\diamond$ & Fault \\
\hline
\end{tabular}

Fig. 9 Principal components analysis (PCA) of selected minor- and traceelement data for white mica. a, c The log-transformed data plotted in PC1 vs. PC2 and PC1 vs. PC 3 planes. b, d Element vectors in the

$\left(D^{\text {tur } / \text { mica }}=0.6\right.$ to 200 , median $=5.93$ to 9.94$)$. These apparent $D$ values, while quite variable, are in reasonable agreement with the limited data in the literature, which are currently restricted to a study of the Mashhad granite, Iran (Zall et al. 2019), $\mathrm{Zn}-\mathrm{Pb}-\mathrm{Ag}$ mineralization at Broken Hill, Australia, corresponding planes. MRS mica-rich selvages, MPS mica-poor selvages, FG fine-grained, rims rims or overgrowths on mica from the greisen. Dashed outlines in $\mathbf{b}$ and $\mathbf{d}$ highlight element clusters

and high-P/T metamorphic rocks from Syros, Greece (Klemme et al. 2011) (Fig. 12a). Importantly, in all previous studies and in our results from Panasqueira, the apparent $D$ values for individual elements are highly variable, which is contrary to expectation for equilibrium partitioning between 
the two minerals. For Panasqueira, tur/mica $D$ values vary by up to 3 orders of magnitude for some elements (e.g., Cs in Fig. 11c), even though the measured grains are in direct contact and appear to be coeval.

Possible explanations for the variation in element partitioning are that the mineral pairs did not reach chemical equilibrium, or that equilibrium was achieved but not maintained, or that the analyses are affected by microscopic mineral inclusions. Although we avoided all visible inclusions during analysis and excluded element spikes and troughs when integrating the laser ablation ICP-MS time-resolved spectra, tourmaline signals were commonly noisy, and incorporation of sub-micron inclusions cannot be excluded. There is evidence that white mica and tourmaline pairs from these samples reached B-isotope equilibrium (Codeço et al. 2019), but this does not necessarily argue for chemical equilibrium since chemical and B-isotope variations in tourmaline are commonly decoupled (Krienitz et al. 2008; Galbraith et al. 2009; Su et al. 2016; Codeço et al. 2017; Albert et al. 2018). The mineralization and alteration at Panasqueira involved dynamic processes and multiple stages, and this is reflected by the chemical zonation in tourmaline. White mica generally lacks zonation with the exception of mica from the greisen, so it may have re-equilibrated to changing conditions, while tourmaline could not due to its slow volume diffusion (e.g., van Hinsberg et al. 2011). If so, white mica may be in chemical equilibrium with the outer rim of coexisting tourmaline, but we cannot test this because the small size of the tourmaline grains makes reliable trace-element analysis of rims impossible.

On the other hand, the possibility that unseen mineral inclusions cause apparent disequilibrium element partitioning is very likely. Laser ablation ICP-MS profiles of some tourmaline grains show large oscillations, and a plot of $\mathrm{Rb}$ and $\mathrm{Cs}$ variations in tourmaline shows a correlation trend that extrapolates directly to the compositions of white mica in the same samples (Fig. 12b). Therefore, if mica inclusions affected the $\mathrm{Rb}$ and $\mathrm{Cs}$ concentrations, we expect that other elements also concentrated in mica $(\mathrm{K}, \mathrm{Ba}, \mathrm{Tl})$ will be affected, and this could explain the near-vertical trends in mica-tourmaline correlation plots of $\mathrm{Rb}, \mathrm{Cs}, \mathrm{Tl}, \mathrm{W}$, and $\mathrm{Sn}$ (Figs. 11b-f). Inclusions are also consistent with the tourmaline PCA results mentioned above. There is a clear separation between the "true" tourmaline composition ( $\mathrm{PC} 1$, positive plane) and mica inclusions (PC1, negative plane) (Fig. 10).

In conclusion, we suggest that the apparent lack of equilibrium between tourmaline and white mica may reflect the greater ability of white mica to adjust to changing fluid compositions during mineralization, as shown by differences in zoning of the two minerals, but there is definitely some effect of sub-microscopic inclusions in tourmaline. For tourmalinemica partitioning, any mica inclusions in tourmaline would shift the apparent $D$ values closer to unity, so the measured values farthest from 1 could be closest to the "true" partitioning between tourmaline and mica.

\section{Estimating the fluid composition from white mica compositions}

Given that white mica from Panasqueira is enriched in the majority of the mineralization-related trace elements, we can test its value as a recorder of fluid composition by comparing a calculated fluid composition based on our data with LA-ICP-MS analyses of fluid inclusions by Lecumberri-Sanchez et al. (2017). Unfortunately, mica-fluid element partition coefficients have only been determined for a few elements (Green and Adam 2003; Wunder and Melzer 2003), and these do not include the Panasqueira ore elements. As an alternative, we calculated mineral-fluid $D$ values for the elements of interest by combining mineral-melt and melt-fluid $D$ values following the approach of Keppler (1996). Table 1 shows apparent mica-fluid $D$ values derived from empirical mica-melt partitioning values of Kovalenko and Antipin (1980), based on white mica phenocrysts and groundmass in ongonites (volcanic equivalent to $\mathrm{Sn}-\mathrm{W}$ granites), combined with experimental melt-fluid $D$ values from Zajacz et al. (2008). The $D$ values in Table 1 should be taken as a first approximation because the ongonite study and the fluid/melt experiments do not represent the same melt composition and $\mathrm{P}-\mathrm{T}$ conditions; there is a significant spread in the melt/ fluid $D$ values of Zajacz et al. (2008) depending on $\mathrm{Cl}$ contents; and none of the experiments were done for the low salinities $(5-10 \mathrm{wt} \% \mathrm{NaCl})$ found in fluid inclusions from the Panasqueira veins. Given these uncertainties, the predicted fluid compositions (Table 1; Fig. 12c) are qualitative, but there is reasonable agreement with measured fluid compositions in quartz-hosted fluid inclusions from Panasqueira (Lecumberri-Sanchez et al. 2017). Note that in that study, high Sn concentrations in the host quartz $(\sim 50 \mathrm{ppm})$ meant that the detection limit for $\mathrm{Sn}$ in the included fluids was around $100 \mathrm{ppm}$, which is at the upper limit of Sn concentrations calculated from the mica concentrations (Fig. 12c). The fluid compositions calculated from mica compositions in different settings within the deposit suggest increasing $\mathrm{Li}, \mathrm{Cs}$, and $\mathrm{Sn}$ contents and decreasing $\mathrm{W}$ and $\mathrm{Zn}$ in the order from the greisen to the veins to the fault zone.

Fluorine and chlorine are important ligands in hydrothermal solutions generally, and they can play a significant role in $\mathrm{Sn}$ and $\mathrm{W}$ transport and precipitation (Manning and Henderson 1984; Schröcke et al. 1984; Heinrich 1990; Keppler and Wyllie 1991; Bai and Koster van Groos 1999; Wood and Samson 2000; 

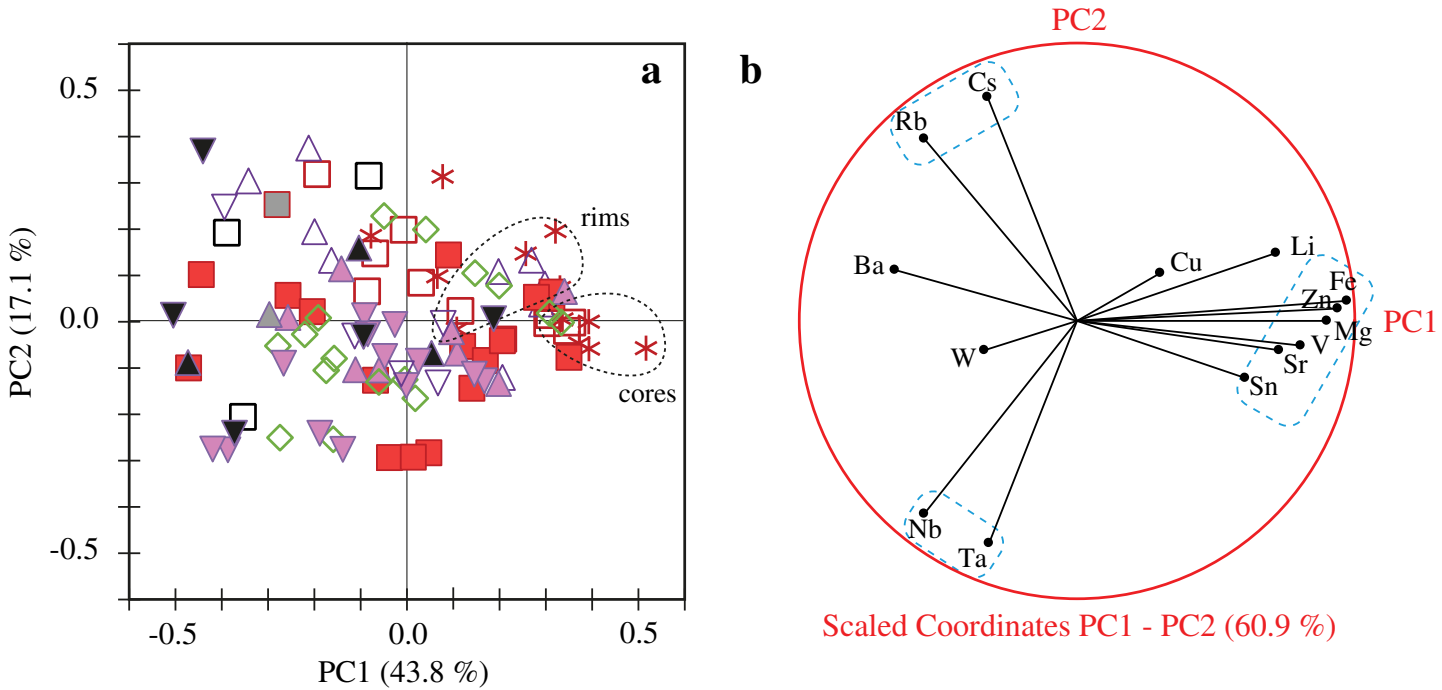

Scaled Coordinates PC1 - PC2 (60.9\%)
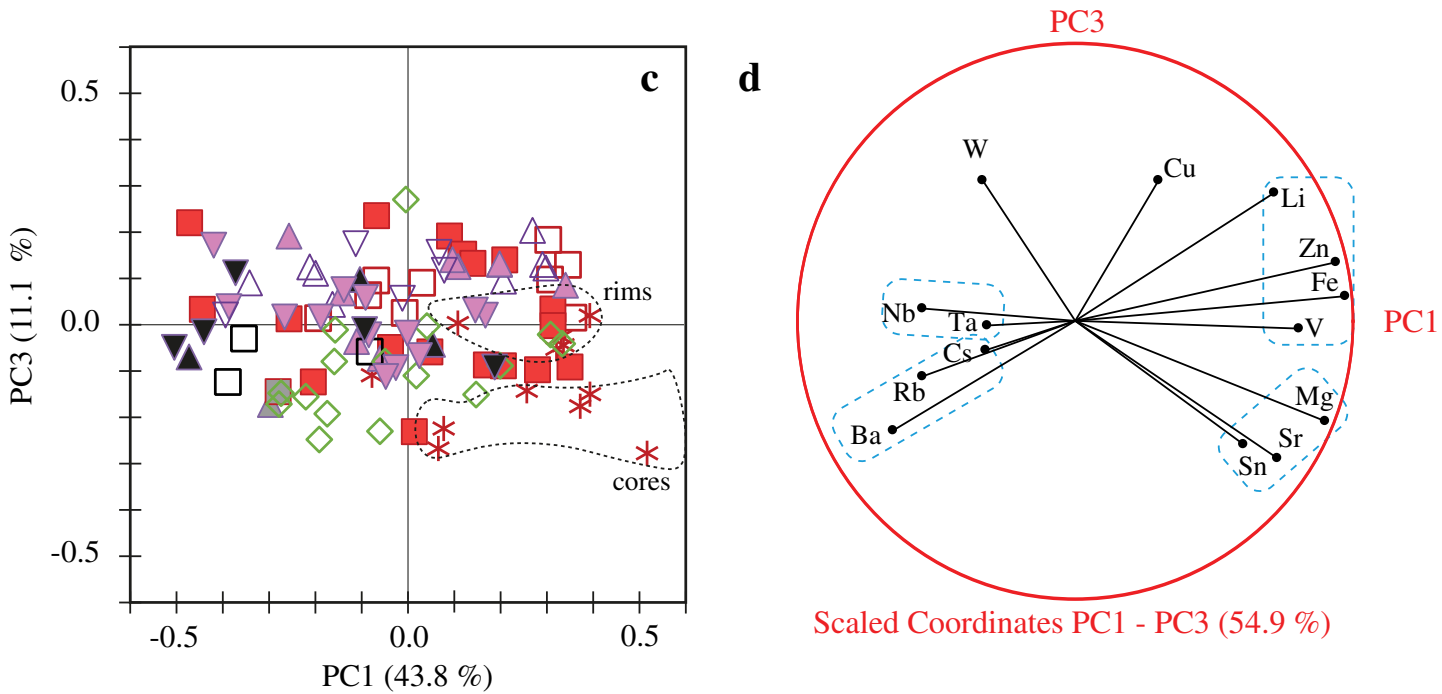

Scaled Coordinates PC1 - PC3 (54.9\%)
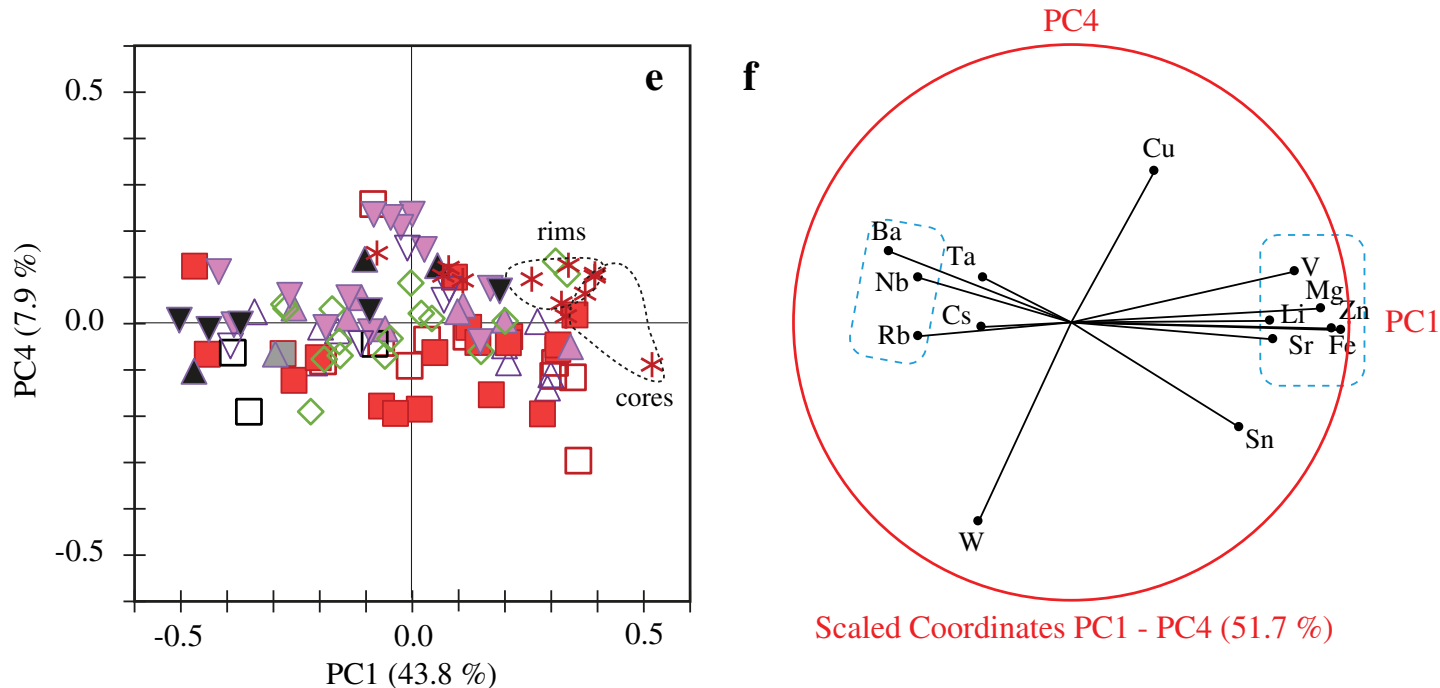

Scaled Coordinates PC1 - PC4 (51.7\%)

\begin{tabular}{|lllll|}
\hline$\square$ MRS (PN22B) & $\square$ MRS (PN46B) & $\square$ MRS (PN33A) & $\square$ MPS (PN30C) & $*$ Late-vugs \\
$\triangle$ Wr-prox (PN22B) & $\triangle$ Wr-prox (PN46B) & $\triangle$ Wr-prox (PN33A) & $\Delta$ Wr-prox (PN30C) & $\diamond$ Fault \\
& $\nabla$ Wr-dist (PN46E) & $\nabla$ Wr-dist (PN33D) & $\nabla$ Wr-dist (PN30D) &
\end{tabular}


Fig. 10 Principal components analysis (PCA) of selected major-, minorand trace-element data for tourmaline. Plots a, c, and e show logtransformed data in the PC1 vs. PC2 and PC1 vs. PC3 planes; plots b, $\mathbf{d}$, and $\mathbf{f}$ display element vectors on the corresponding planes. MRS micarich selvages, MPS mica-poor selvages, Wr-prox wall rock proximal to the vein contact, Wr-dist wall rock distal from the vein contact. Dashed outlines in $\mathbf{b}, \mathbf{d}$, and $\mathbf{f}$ highlight element clusters

Schmidt 2018), as well as in fluid-mineral partitioning (Zajacz et al. 2008). At Panasqueira, $\mathrm{Cl}$ is below the detection limit of LA-ICP-MS in both mica and tourmaline (5 and $6 \mathrm{ppm}$, respectively) which is consistent with the low salinity indicated by fluid inclusion studies (Kelly and Rye 1979; Bussink 1984; Jaques and Pascal 2017; Lecumberri-Sanchez et al. 2017). Fluorine analysis is not possible by LA-ICP-MS, but microprobe measurements of mica adjacent to LA-ICP-MS spots indicate $\mathrm{F}$ contents up to $3.2 \mathrm{wt} \%$ (Codeço et al. 2019). Lithium data from LA-ICP-MS and F concentrations from electron microprobe analysis (Fig. 12b) shows a good linear correlation, as described from other localities (Tischendorf et al. 1997; ESM 3). Figure $12 \mathrm{~d}$ also shows that $\mathrm{Li}$ and $\mathrm{F}$ contents in mica increase systematically from the greisen to the fault zone, which is further evidence for an evolution of the hydrothermal fluid from early stages to later stages in the Panasqueira system.

\section{Potential of white mica and tourmaline as fluid tracers}

The observation that the trace elements most affected by alteration (Fig. 8a) preferentially partition into white mica over tourmaline suggests that mica is better suited as a pathfinder mineral and a fluid tracer in the Panasqueira example. This is partly an effect of the different settings of the two minerals in the hydrothermal system. Most tourmalines at Panasqueira formed in alteration zones in fine-grained metasediments, where it replaced pre-existing minerals. Thus, its trace-element contents reflect both the compositions of the hydrothermal fluid and that of the host rocks. Other studies of hydrothermal tourmaline reached the conclusion that the major- and trace-element signatures are largely controlled by the local host rock composition and that relatively few elements, e.g., Li, are distinctive of the fluid source (Kalliomäki et al. 2017). Further complications in the case of Panasqueira are the fine grain size of tourmaline, the presence of compositional zoning, and the abundance of inclusions, which are beyond the spatial resolution of LA-ICP-MS analyses. In contrast, mica in the vein selvages likely precipitated directly from the mineralizing fluids and is large enough for precise in situ analysis.
To investigate the potential of white mica and tourmaline as pathfinders for ore deposits of the W-Sn type more generally, we compared results from this study of Panasqueira with data from other $\mathrm{Sn}-\mathrm{W}$ deposits as well as hydrothermal deposits with different metal associations (e.g., $\mathrm{Cu}-\mathrm{Au}-\mathrm{Mo}, \mathrm{Pb}-\mathrm{Zn}$ ). Unfortunately, only a few studies report trace-element compositions of mica and most of those are for trioctahedral micas (Maoping, Legros et al. 2016; Piotang, Legros et al. 2018; Cínovec/Zinnwald, Breiter et al. 2017; Qiluling, Xie et al. 2015; Yashan, Li et al. 2015). All Panasqueira micas are dioctahedral, so the comparison needs to be interpreted with caution. Nevertheless, we find that mica with W-Sn association has higher Rb, Cs (Li), and Sn contents compared with that from porphyry $\mathrm{Cu}$ and VMS base-metal deposits, whereas the range of W contents overlaps (Fig. 13a-c). Most mica from WSn deposits, including Panasqueira, has $>10 \mathrm{ppm} \mathrm{W}$, while mica from the majority of porphyry deposits has $\mathrm{W}$ contents between 1 and $10 \mathrm{ppm}$. Early mica from the Piaotang deposit, which is coeval with cassiterite, yielded lower $\mathrm{W}$ contents than later mica from that deposit, indicating that it can record changing conditions (Legros et al. 2018). There are no data for $\mathrm{Zn}$ and $\mathrm{Cu}$ in mica from the other W-Sn deposits, but our Panasqueira data overlap in terms of these elements with mica from VMS and porphyry deposits (Fig. 13d).

A similar comparison for tourmaline shows higher $\mathrm{Sn}$ and $\mathrm{Li}$ contents in that mineral from $\mathrm{Sn}-\mathrm{W}$ deposits relative to tourmaline from the Salikvan $\mathrm{Cu}-\mathrm{Mo}$ porphyry deposit and orogenic gold deposits (Fig. 13e), but no significant difference was found for W, except for the Salikvan deposit (Fig. 13f). The Sn-Li plot also discriminates between $\mathrm{Sn}-\mathrm{W}$ deposits in the Massif Central and deposits with $\mathrm{W}$ only. The strong overlap of all deposits on the $\mathrm{V}$ and $\mathrm{Sr}$ plot (Fig. 13g) supports the interpretation that these elements are host rock controlled and depend on the local lithogeochemistry rather than mineralizing fluids (Kalliomäki et al. 2017). The range of $\mathrm{Cu}$ concentrations in tourmaline is similar and highly variable in all deposits, but $\mathrm{Zn}$ contents tend to be higher at Panasqueira than in all other $\mathrm{Sn}-\mathrm{W}$ deposits (Fig. 13h). This may reflect the high sphalerite content in the Panasqueira veins.

Even though tourmaline compositions are less responsive to the composition of the hydrothermal fluid than white mica, our compilation suggests that high $\mathrm{Sn}$ and Li contents in tourmaline (i.e., > $10 \mathrm{ppm}$ and $50 \mathrm{ppm}$, respectively) are distinctive for magmatic-hydrothermal $\mathrm{Sn}$ deposits. In any case, given that mica and tourmaline tend to occur together in hydrothermal systems and incorporate different sets of trace elements, the best approach for geochemical pathfinding using alteration minerals would be to combine information from both minerals. 

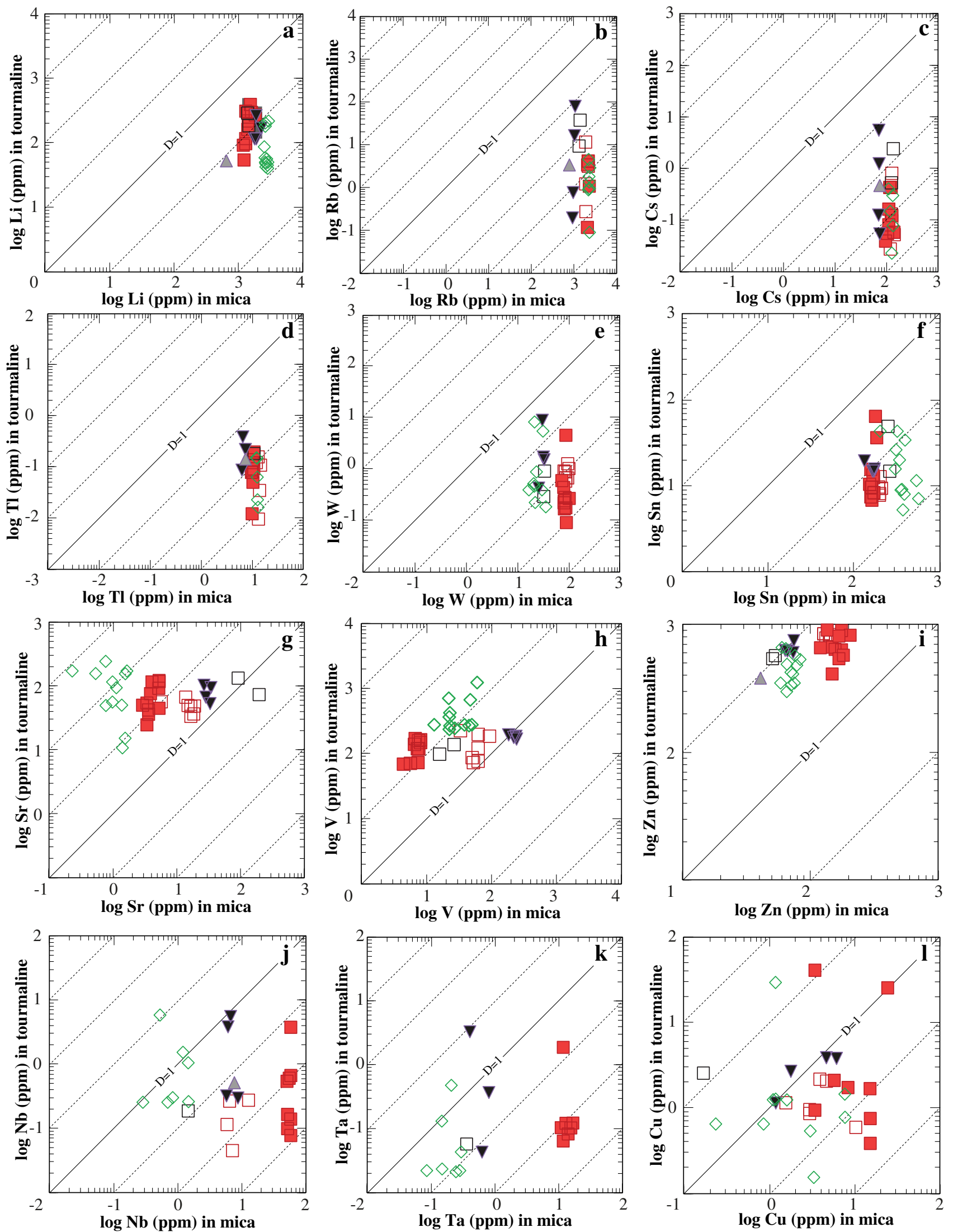

MRS (PN46B) $\square$ MRS (PN33A) $\square$ MPS (PN30C) $\quad \nabla$ Wr-dist (PN30D) $\diamond$ Fault 
Fig. 11 Partitioning of selected trace elements between mica and tourmaline. a $\log \mathrm{Li}$ in mica vs. $\log \mathrm{Li}$ in tourmaline. $\mathbf{b} \log \mathrm{Rb}$ in mica vs. $\log \mathrm{Rb}$ in tourmaline. $\mathbf{c} \log \mathrm{Cs}$ in mica vs. $\log$ Cs in tourmaline. $\mathbf{d} \log$ $\mathrm{Tl}$ in mica vs. $\log \mathrm{Tl}$ in tourmaline. e Log $\mathrm{W}$ in mica vs. $\log \mathrm{W}$ in tourmaline. $\mathbf{f} \log \mathrm{Sn}$ in mica vs. $\log \mathrm{Sn}$ in tourmaline. $\mathbf{g} \log \mathrm{Sr}$ in mica vs. $\log$ Sr in tourmaline. $\mathbf{h} \log \mathrm{V}$ in mica vs. $\log \mathrm{V}$ in tourmaline. $\mathbf{i} \log \mathrm{Zn}$ in mica vs. $\log \mathrm{Zn}$ in tourmaline. $\mathbf{j} \log \mathrm{Nb}$ in mica vs. $\log \mathrm{Nb}$ in tourmaline. $\mathbf{k} \log \mathrm{Ta}$ in mica vs. $\log \mathrm{Ta}$ in tourmaline. $\mathbf{I} \log \mathrm{Cu}$ in mica vs. $\log \mathrm{Cu}$ in tourmaline. The slanted lines represent apparent $D$ values (see text). MRS mica-rich selvages, MPS mica-poor selvages, Wr-dist wall rock distal from the vein contact

\section{Conclusions}

White mica, tourmaline, and quartz are the most abundant hydrothermal minerals in the alteration assemblages at the Panasqueira $\mathrm{W}-\mathrm{Sn}-\mathrm{Cu}$ deposit, where mica forms thick vein selvages at the contacts with the host rocks, and tourmaline predominately occurs in the alteration halos. To explore the potential of hydrothermal minerals as indicators for mineralization at Panasqueira, we determined the trace-element contents of unaltered and

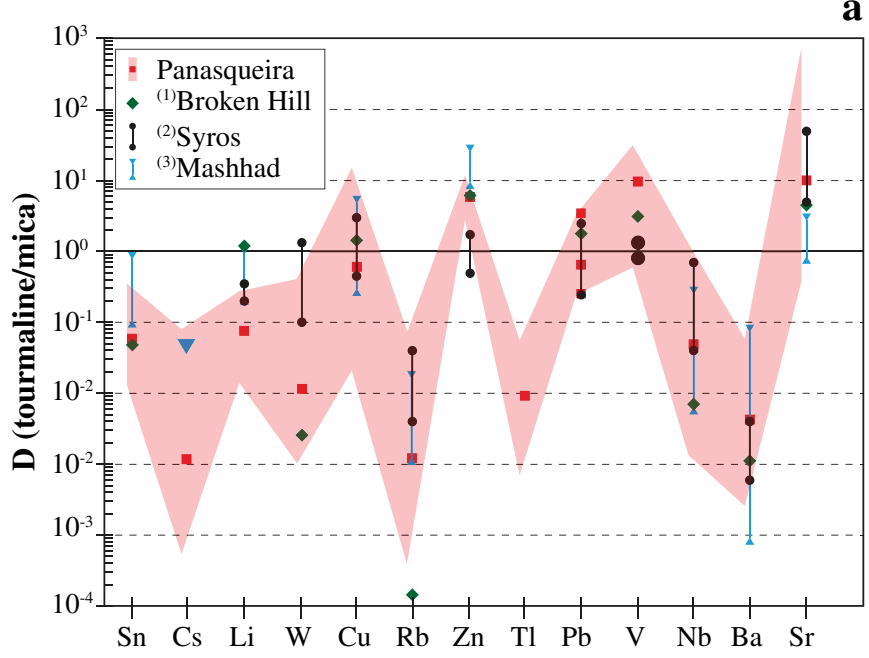

c

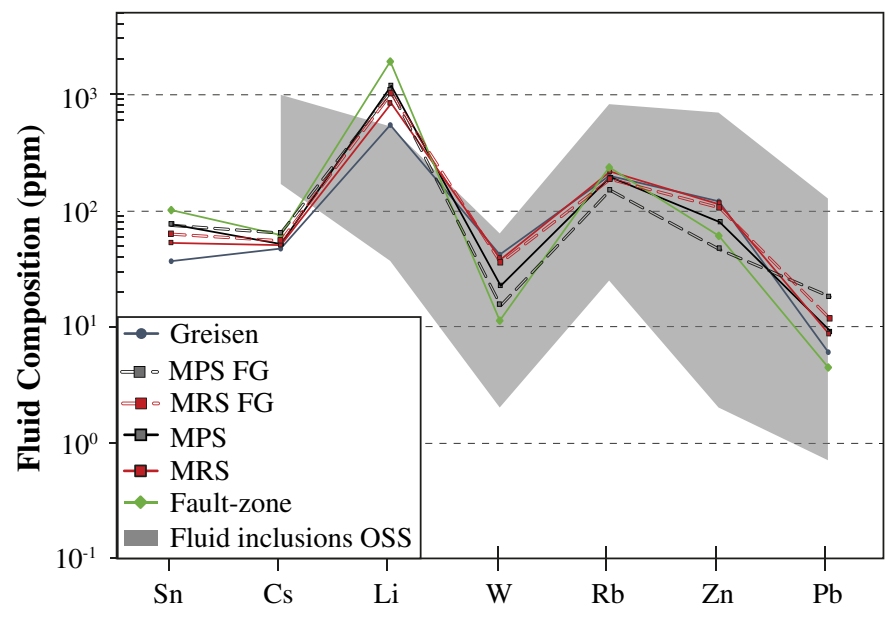

Fig. 12 a Trace-element partitioning between tourmaline and mica from Panasqueira expressed as apparent $D$ values. The red squares show the median values for each element, and the shadowed field corresponds to the full range of values. Also shown for comparison is the range of apparent $D$ values for tourmaline-mica data from Broken Hill, Australia (Klemme et al. 2011); Syros, Greece (Marschall 2005 in Klemme et al. 2011); and the Mashhad granite, Iran (Zall et al. 2019). b Variation of Rb and $\mathrm{Cs}$ concentrations in coexisting tourmaline and white mica from the samples illustrated in Fig. 11. The wide range of $\mathrm{Rb}$ and $\mathrm{Cs}$ contents in
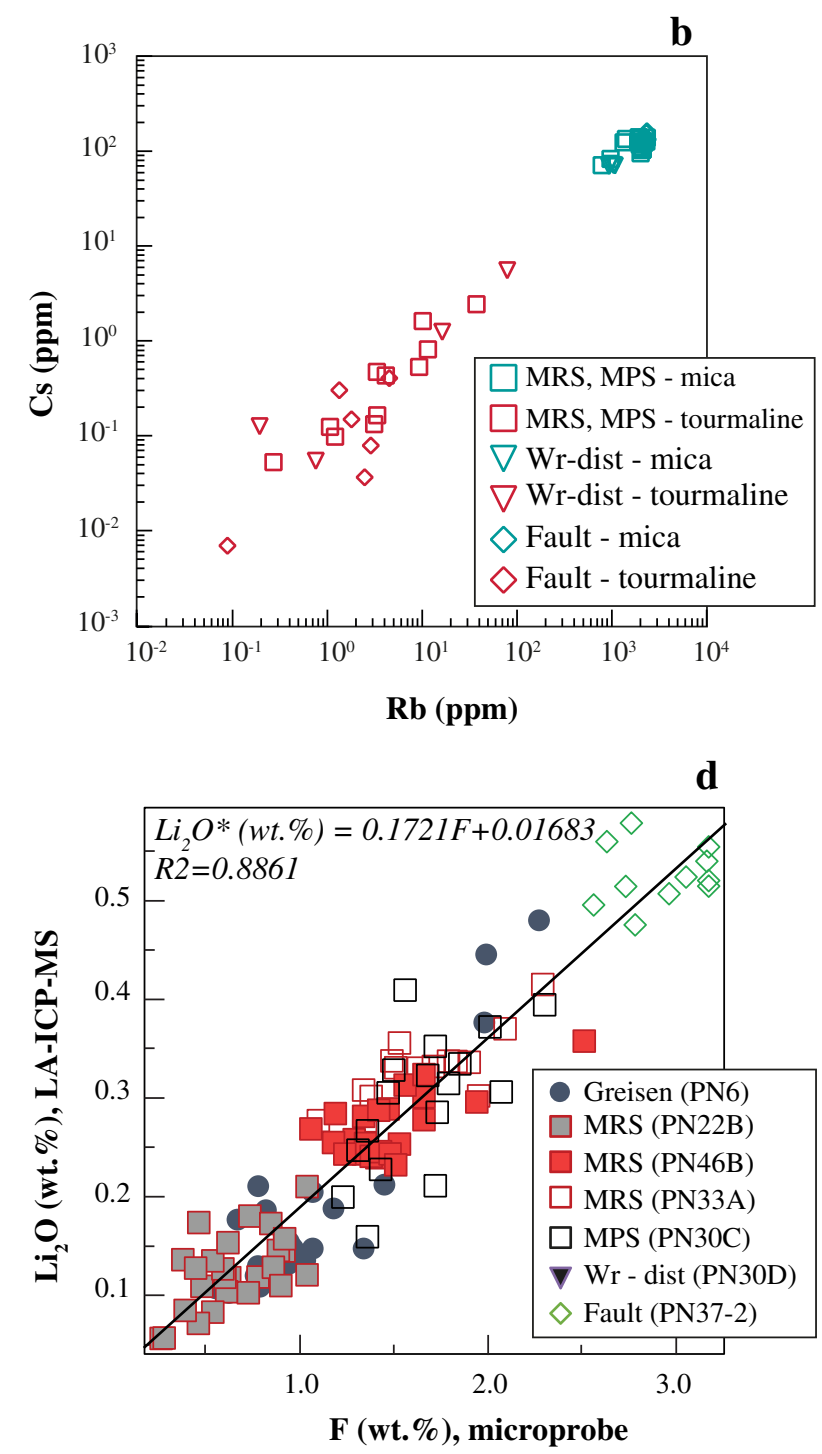

tourmaline is attributed to microinclusions of mica (see text). c Comparison between modeled (curves) and measured (shaded area) trace-element concentrations in the Panasqueira hydrothermal fluid. The modeled values are based on white mica compositions and mica-fluid $D$ values (this work), and measurements are LA-ICP-MS analysis in quartzhosted fluid inclusions representing the oxide-silicate stage (OSS) from Lecumberri-Sanchez et al. (2017). Note that the detection limit for $\mathrm{Sn}$ in the fluid inclusions was at 100 ppm (see text). d Correlation between F determined by microprobe and $\mathrm{LiO}_{2}$ measured by LA-ICP-MS 
Table 1 Apparent partition coefficients of mica-fluid $\left(D_{\mathrm{ms} / \mathrm{fl}}\right)$ used in this study to reconstruct fluid compositions from analyses of white mica

\begin{tabular}{|c|c|c|c|c|c|c|}
\hline & \multirow[t]{2}{*}{$D_{\mathrm{ms} / \mathrm{fl}}^{\mathrm{i}}$} & \multicolumn{5}{|c|}{ Reconstructed fluid composition (ppm) ${ }^{\mathrm{ii}}$} \\
\hline & & All vein mica & MPS $^{\text {iv }}$ & $\mathrm{MRS}^{\mathrm{v}}$ & Fault & Greisen \\
\hline $\mathrm{Na}$ & 0.17 & 24,012 & 24,814 & 24,690 & 6815 & 23,843 \\
\hline $\mathrm{K}$ & 8.7 & 10,060 & 9984 & 9975 & 10,115 & 10,028 \\
\hline $\mathrm{Rb}$ & $9.6^{\mathrm{vi}}$ & 201 & 177 & 207 & 237 & 200 \\
\hline Cs & 2.1 & 54 & 53 & 52 & 61 & 47 \\
\hline $\mathrm{Li}$ & 1.4 & 940 & 815 & 865 & 1942 & 549 \\
\hline $\mathrm{Pb}$ & 0.21 & 9.9 & 13 & 9.6 & 4.1 & 6.0 \\
\hline $\mathrm{Sr}$ & 0.56 & 24 & 50 & 19 & 1.9 & 3.1 \\
\hline $\mathrm{Ba}$ & 0.26 & 2079 & 3303 & 1741 & 1466 & 217 \\
\hline $\mathrm{Mg}$ & 2.5 & 2888 & 3960 & 2025 & 7495 & 372 \\
\hline $\mathrm{Zn}$ & 1.1 & 94 & 73 & 113 & 61 & 121 \\
\hline $\mathrm{Mn}$ & 4.0 & 85 & 72 & 89 & 131 & 156 \\
\hline $\mathrm{Fe}$ & 595 & 35 & 29 & 37 & 44 & 39 \\
\hline $\mathrm{Al}$ & 50 & 3625 & 3672 & 3636 & 3019 & 3779 \\
\hline B & $0.92^{\mathrm{vi}}$ & 65 & 57 & 65 & 126 & 55 \\
\hline $\mathrm{Sn}$ & 3.3 & 60 & 63 & 58 & 101 & 37 \\
\hline $\mathrm{Nb}$ & 121 & 0.05 & 0.03 & 0.06 & 0.01 & 1.0 \\
\hline W & 2.2 & 36 & 26 & 38 & 11 & 42 \\
\hline
\end{tabular}

${ }^{\mathrm{i}}$ Calculated by combining empirical mica-melt and experimental fluid-melt partition coefficients from Kovalenko and Antipin (1980) and Zajacz et al. (2008), respectively (see text)

${ }^{i i}$ Fluid composition based on the median value of mica analyses from the given setting

iii Based on the median values of MRS and MPS mica analyses combined

${ }^{\text {iv }}$ Mica-rich selvage

${ }^{\mathrm{v}}$ Mica-poor selvage

${ }^{v i}$ Based on the maximum value of partition coefficients of mica-melt reported by Kovalenko and Antipin (1980) altered rock samples by whole rock analyses and of hydrothermal white mica and tourmaline by in situ LA-ICP-MS. The resulting data were investigated with the help of principal component analysis (PCA).

The alteration zone is characterized by enrichments in As, $\mathrm{Sn}, \mathrm{Li}, \mathrm{W}, \mathrm{F}, \mathrm{Cu}, \mathrm{Rb}, \mathrm{Zn}, \mathrm{Tl}$, and $\mathrm{Pb}$ as delineated by PCA results from the whole-rock data. These elements strongly load on the first principal component (PC1) of the variability, whereas PC2 is interpreted to reflect the different modal abundances of minerals such as mica and tourmaline. PC3 identifies a subordinate geochemical variation as a function of distance from the greisen, which is mineralogically controlled, with proximal zones enriched in $\mathrm{Rb}$, Cs, and $\mathrm{Tl}$ reflecting thick mica selvages and the distal zones richer in As, $\mathrm{Zn}$, and $\mathrm{Cu}$ reflecting sulfide vein mineralization.

The in situ LA-ICP-MS data show that $\mathrm{Rb}, \mathrm{Cs}, \mathrm{Ba}$, $\mathrm{Li}, \mathrm{Nb}, \mathrm{Ta}, \mathrm{W}$, and $\mathrm{Sn}$ preferentially partition into white mica over tourmaline while $\mathrm{Zn}, \mathrm{V}$, and $\mathrm{Sr}$ do the opposite. Thus, white mica better reflects the hydrothermal fluid and its evolution. Fine-grained mica at the wall rock contact zone has lower $\mathrm{Rb}$ and $\mathrm{W}$ contents (and $\mathrm{Zn}$ in some cases) but higher $\mathrm{Mg}, \mathrm{Sr}, \mathrm{V}$, and $\mathrm{Sn}$ contents compared to mica of the main vein-selvage and the greisen body. This suggests that the micas at the contact zone partially reflect the composition of the host rock. In addition to a temporal evolution, the PCA results for white mica show a clear clustering by

Fig. 13 Trace-element concentrations in micas (a to d) and tourmaline (e to h) from Panasqueira and other hydrothermal deposits worldwide. Studies from Piaotang W-Sn (Legros et al. 2018), Yashan W-Ta-Nb (Li et al. 2015), and Qiguling rhyolite (Furong Sn) (Xie et al. 2015) include trioctahedral and dioctahedral micas; Maoping W-Sn (Legros et al. 2016) and Cinovec/Zinnwald Sn-W-Li (Breiter et al. 2017) only comprise trioctahedral micas; data from other ore deposits are only dioctahedral micas: Ann-Mason porphyry $\mathrm{Cu}$ (Cohen 2011), Copper Cliff porphyry $\mathrm{Cu}$ (Uribe-Mogollon and Maher 2018), and Bathurst Mining Camp VMS (Soltani Dehnavi et al. 2018). Data sources for tourmaline are: Duchoslav et al. (2017) —Cornwall Sn-W; (Harlaux (2016) Enguialès and St-Mélany-French Massif Central (FMC); Jiang et al. (2004)_Yunlong Sn; Harlaux et al. (2019)_Puy-les-Vignes, French Massif Central W; Hazarika et al. (2017)—Hutti-Maski (Au); Trumbull et al. (2019) and Cabral et al. (2012)_Passagem de Mariana (Au); Kalliomäki et al. (2017) - Archean Hattu Schist Belt (Au); and Yavuz et al. (1999) - Salikvan porphyry $\mathrm{Cu}-\mathrm{Mo}$ porphyry deposit. $\mathrm{PCu}$ and $\mathrm{PCu}-\mathrm{Mo}$ porphyry $\mathrm{Cu}$ and $\mathrm{Cu}-\mathrm{Mo}$ deposits, respectively, VMS volcanogenic massive sulfide deposits, FMC French Massif Central 

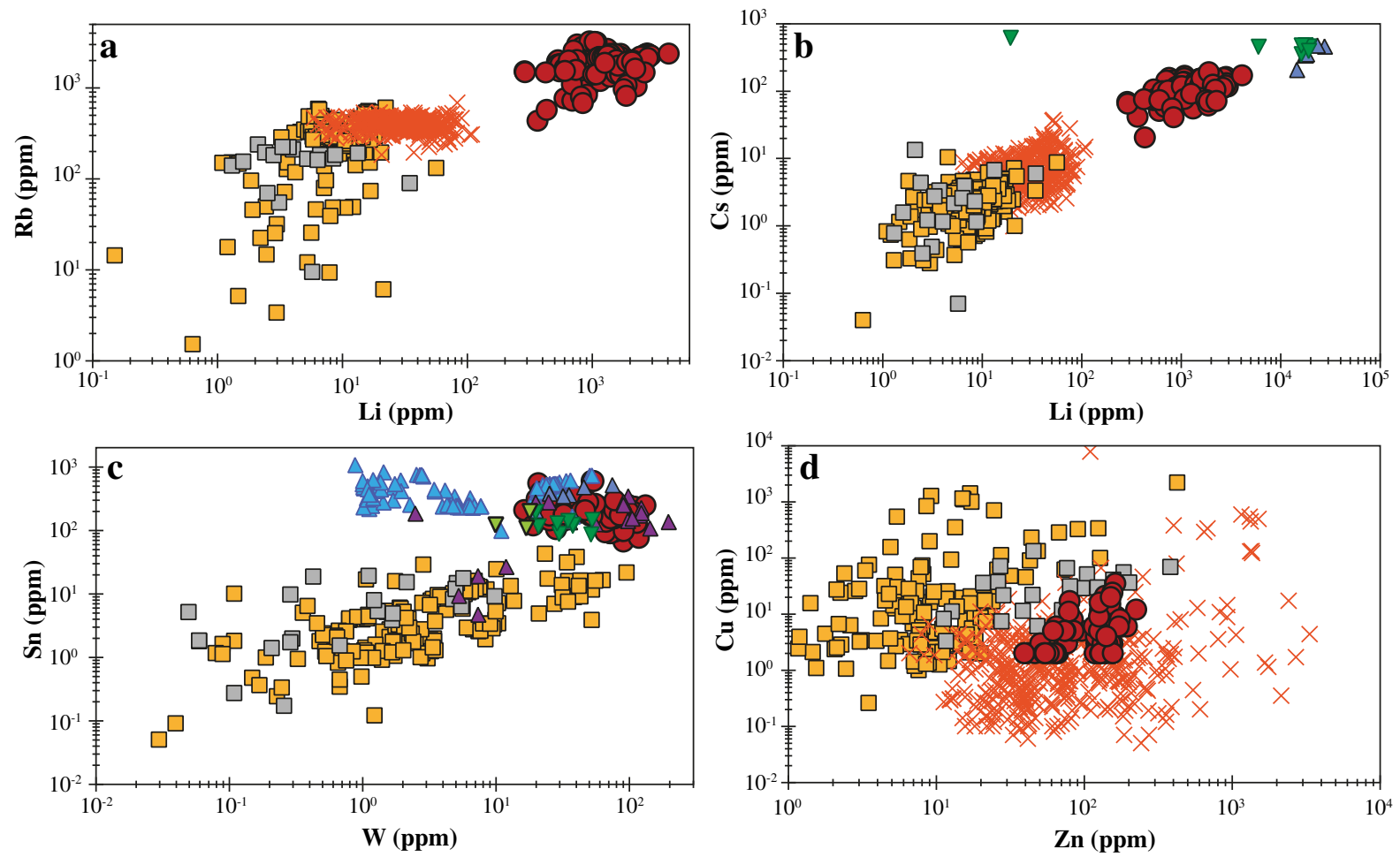

\begin{tabular}{|c|c|c|}
\hline \multicolumn{2}{|c|}{ W-SN ORE DEPOSITS } & OTHER ORE DEPOSITS \\
\hline$\Delta$ Piaotang & $\triangle$ Maoping & $\square \quad$ Ann-Mason PCu \\
\hline$\Delta$ Yashan & $\nabla$ Cinovec/Zinnwald & $\square \quad$ Copper Cliff $\mathrm{PCu}$ \\
\hline $\bar{\nabla}$ Furong & This study & $\times \quad$ Bathurst VMS \\
\hline
\end{tabular}
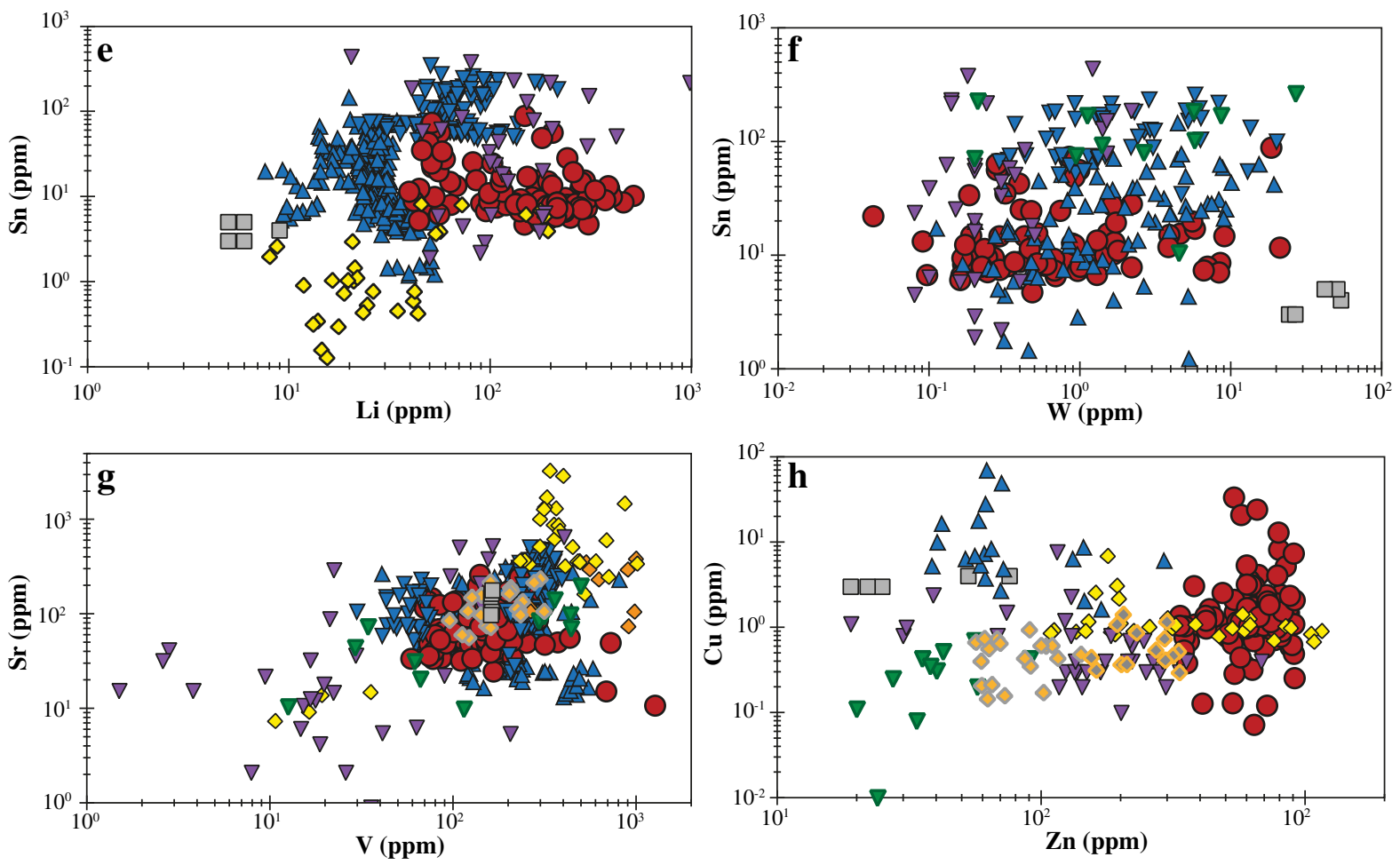

\begin{tabular}{|lllll|}
\hline \multicolumn{2}{|c|}{ W-SN ORE DEPOSITS } & \multicolumn{2}{c|}{ OTHER ORE DEPOSITS } \\
$\nabla$ & Cornwall & $\Delta$ Puy-les-Vignes, FMC & $\diamond$ Hutti-Mask Au & $\diamond$ Hattu Schist Belt Au \\
$\nabla$ & FMC Sn-W & $\bigcirc$ This study & $\diamond$ Passagem de Mariana Au & $\square$ Salikvan PCu-Mo \\
$\nabla$ & Yunlong & & $\diamond$ Passagem de Mariana Au & \\
\hline
\end{tabular}


setting, distinguishing the greisen, vein selvages, and late fault zones from each other. The trace-element composition of hydrothermal fluid calculated from approximated fluid-mica partition coefficients shows reasonable agreement with measured compositions of quartz-hosted fluid inclusions and suggests an evolution of the fluid from greisen formation to vein selvage (MRS) to latestage mineralized fault zones, with progressive increases in $\mathrm{Li}, \mathrm{Cs}$, and $\mathrm{Sn}$ with time and fluctuation in $\mathrm{Sn} / \mathrm{W}$ ratios. The mica data and fluid modeling suggest that fluids released from the granitic intrusion were responsible for the hydrothermal alteration. Comparisons of mica data from Panasqueira and other deposits suggest that white mica has a great potential as a pathfinder for $\mathrm{W}-\mathrm{Sn}$ mineralization with characteristically high $\mathrm{Rb}$, $\mathrm{Cs}, \mathrm{Li}, \mathrm{Sn}$, and $\mathrm{W}$ contents.

In contrast to white mica, tourmaline at Panasqueira mainly forms by mineral replacement in the host rock, and its composition is less influenced by the hydrothermal fluid. The PCA results from tourmaline data are complex, and the variability is complicated by analytical issues related to mineral and fluid inclusions, as well as by chemical zoning that cannot be spatially resolved by LA-ICP-MS analysis. Despite this, the comparison of tourmaline data from Panasqueira and other hydrothermal ore deposits suggests that high $\mathrm{Sn}$ and $\mathrm{Li}$ contents in hydrothermal tourmaline are indicative for $\mathrm{Sn}-\mathrm{W}$ mineralization.

Acknowledgments We are particularly indebted to U. Altenberger (Universität Potsdam, Germany) and A. Jung (University McGill, Canada) for their support with the SEM and LA-ICP-MS analyses. We further thank F. Rosendahl for help with sample preparation and A. Gottsche and H. Rothe for performing the XRF and ICP-MS analyses at GFZ. We also thank M. Korges and A. Mateus for many inspiring discussions. The authors are grateful to the editors, Georges Beaudoin and Alexandre Raphael Cabral, and Frederico Guimarães, Gordana Garapić, and two anonymous reviewers for their constructive comments and suggestions, which helped to improve the manuscript. Beralt Tin and Wolfram (Portugal) S.A. are acknowledged for providing logistical support and access to the Panasqueira deposit over two field seasons.

Funding information Open Access funding provided by Projekt DEAL. The project was funded by the German Federal Ministry of Education and Research (BMBF) within the project GRAMME (033R149).

Open Access This article is licensed under a Creative Commons Attribution 4.0 International License, which permits use, sharing, adaptation, distribution and reproduction in any medium or format, as long as you give appropriate credit to the original author(s) and the source, provide a link to the Creative Commons licence, and indicate if changes were made. The images or other third party material in this article are included in the article's Creative Commons licence, unless indicated otherwise in a credit line to the material. If material is not included in the article's Creative Commons licence and your intended use is not permitted by statutory regulation or exceeds the permitted use, you will need to obtain permission directly from the copyright holder. To view a copy of this licence, visit http://creativecommons.org/licenses/by/4.0/.

\section{References}

Aitchison J (1982) The statistical analysis of compositional data, XII edn. Chapman and Hall, London - New York 1986, p 416

Albert C, Lana C, Gerdes A, Schannor M, Narduzzi F, Queiroga G (2018) Archean magmatic-hydrothermal fluid evolution in the Quadrilátero Ferrífero (SE Brazil) documented by B isotopes (LA MC-ICPMS) in tourmaline. Chem Geol 481:95-109. https://doi.org/10.1016/j. chemgeo.2018.02.002

Bai T, Koster van Groos A (1999) The distribution of Na, K, Rb, Sr, Al, $\mathrm{Ge}, \mathrm{Cu}, \mathrm{W}, \mathrm{Mo}, \mathrm{La}$, and $\mathrm{Ce}$ between granitic melts and coexisting aqueous fluids. Geochim Cosmochim Acta 63:1117-1131. https:// doi.org/10.1016/S0016-7037(98)00284-1

Ballouard C, Poujol M, Boulvais P, Branquet Y, Tartèse R, Vigneresse J$\mathrm{L}$ (2016) Nb-Ta fractionation in peraluminous granites: a marker of the magmatic-hydrothermal transition. Geology 44:231-234. https://doi.org/10.1130/G37475.1

Bos A (1990) Hydrothermal element distributions at high temperatures: an experimental study on the partitioning of major and trace elements between phlogopite, haplogranitic melt and vapour. Utrecht University

Breiter K, Duurišová J, Hrstka T, Korbelová Z, Vaňková MH, Galiová MV, Kanický V, Rambousek P, Knésl I, Dobeš P, Dosbaba M (2017) Assessment of magmatic vs. metasomatic processes in raremetal granites: a case study of the Cínovec/Zinnwald Sn-W-Li deposit, Central Europe. Lithos 292-293:198-217. https://doi.org/ 10.1016/j.lithos.2017.08.015

Breiter K, Hložková M, Korbelová Z, Galiová MV (2019) Diversity of lithium mica compositions in mineralized granite-greisen system: Cínovec Li-Sn-W deposit, Erzgebirge. Ore Geol Rev 106:12-27. https://doi.org/10.1016/j.oregeorev.2019.01.013

Bussink RW (1984) Geochemistry of the Panasqueira tungsten-tin deposit, Portugal. Geol Ultraiect 33:170

Cabral AR, Wiedenbeck M, Koglin N, Lehmann B, De Abreu FR (2012) Boron-isotopic constraints on the petrogenesis of hematitic phyllite in the southern Serra do Espinhaço, Minas Gerais, Brazil. Lithos 140-141:224-233. https://doi.org/10.1016/j.lithos.2012.01.011

Champion DC, Huston DL (2016) Radiogenic isotopes, ore deposits and metallogenic terranes: novel approaches based on regional isotopic maps and the mineral systems concept. Ore Geol Rev 76:229-256. https://doi.org/10.1016/j.oregeorev.2015.09.025

Cheng Q, Bonham-Carter G, Wang W, Zhang S, Li W, Qinglin X (2011) A spatially weighted principal component analysis for multielement geochemical data for mapping locations of felsic intrusions in the Gejiu mineral district of Yunnan, China. Comput Geosci 37: 662-669. https://doi.org/10.1016/j.cageo.2010.11.001

Clark AH (1970) Potassium-argon ages and regional relationships of the Panasqueira tin-tungsten mineralization. Comun dos Serviços Geológicos Port 54:243-261

Codeço MS, Weis P, Trumbull RB, Pinto F, Lecumberri-Sanchez P, Wilke FDHH (2017) Chemical and boron isotopic composition of hydrothermal tourmaline from the Panasqueira W-Sn-Cu deposit, Portugal. Chem Geol 468:1-16. https://doi.org/10.1016/j.chemgeo. 2017.07.011

Codeço MS, Mateus A, Figueiras J, Rodrigues P, Gonçalves L (2018) Development of the Ervidel-Roxo and Figueirinha-Albernoa volcanic sequences in the Iberian pyrite Belt, Portugal: Metallogenic and geodynamic implications. Ore Geol Rev 98:80-108. https://doi.org/ 10.1016/j.oregeorev.2018.05.009

Codeço MS, Weis P, Trumbull RB, Glodny J, Wiedenbeck M, Romer RL (2019) Boron isotope muscovite-tourmaline geothermometry indicates fluid cooling during magmatic-hydrothermal W-Sn ore 
formation. Econ Geol 114:153-163. https://doi.org/10.5382/ econgeo.2019.4625

Codeço MS, Weis P, Trumbull RB, van Hinsberg V, Pinto F, Lecumberri-Sanchez P, Schleicher AM (2020) Trace element contents in white mica and tourmaline from the Panasqueira W-Sn-Cu deposit (Portugal). GFZ Data Services. https://doi.org/10.5880/ GFZ.3.1.2020.002

Cohen JF (2011) Compositional variations in hydrothermal white mica and chlorite from wall-rock alteration at the Ann-Mason porphyry copper deposit. Oregon State University, Nevada

Conde LNN, Pereira V, Ribeiro A, Thadeu D (1971) Jazigos Hipogénicos de Estanho e Volfrâmio. I Congr Hisp Geol Económica 81

Cooke DR, Baker M, Hollings P, Sweet G, Chang Z, Danyushevsky L, Gilbert S, Zhou T, White NC, Gemmell JB, Inglis S (2014) New advances in detecting the distal geochemical footprints of porphyry systems-epidote mineral chemistry as a tool for vectoring and fertility assessments. SEG Spec Publ 18:127-152. https://doi.org/10. 5382/SP.18.07

Croghan CW, Egeghy PP (2003) Methods of dealing with values below the limit of detection using SAS. In: Southern SAS User Group. pp $1-5$

Dill HG (2018) Geology and chemistry of Variscan-type pegmatite systems (SE Germany) - with special reference to structural and chemical pattern recognition of felsic mobile components in the crust. Ore Geol Rev 92:205-239. https://doi.org/10.1016/j.oregeorev.2017.11. 016

Duchoslav M, Marks MAW, Drost K, McCammon C, Marschall HR, Wenzel T, Markl G (2017) Changes in tourmaline composition during magmatic and hydrothermal processes leading to tin-ore deposition: the Cornubian Batholith, SW England. Ore Geol Rev 83: 215-234. https://doi.org/10.1016/j.oregeorev.2016.11.012

Dupuis C, Beaudoin G (2011) Discriminant diagrams for iron oxide trace element fingerprinting of mineral deposit types. Mineral Deposita 46:319-335. https://doi.org/10.1007/s00126-011-0334-y

Dyar MD, Wiedenbeck M, Robertson D, Cross LR, Delaney JS, Ferguson K, Francis CA, Grew ES, Guidotti CV, Hervig RL, Hughes JM, Husler J, Leeman W, McGuire AV, Rhede D, Rothe H, Paul RL, Richards I, Yates M (2001) Reference minerals for the microanalysis of light elements. Geostand Newslett 25:441-463. https://doi.org/10.1111/j.1751-908X.2001.tb00616.x

Filzmoser P, Hron K, Reimann C (2009) Univariate statistical analysis of environmental (compositional) data: problems and possibilities. Sci Total Environ 407:6100-6108. https://doi.org/10.1016/j.scitotenv. 2009.08.008

Foxford KA, Nicholson R, Polya DA (1991) Textural evolution of W$\mathrm{Cu}$-Sn-bearing hydrothermal veins at Minas da Panasqueira, Portugal. Mineral Mag 55:435-445. https://doi.org/10.1180/ minmag.1991.055.380.13

Foxford KA, Nicholson R, Polya DA, Hebblethwaite RPB (2000) Extensional failure and hydraulic valving at Minas da Panasqueira, Portugal: evidence from vein spatial distributions, displacements and geometries. J Struct Geol 22:1065-1086. https://doi.org/10. 1016/S0191-8141(00)00029-8

Fresia B, Ross P-S, Gloaguen E, Bourke A (2017) Lithological discrimination based on statistical analysis of multi-sensor drill core logging data in the Matagami VMS district, Quebec, Canada. Ore Geol Rev 80:552-563. https://doi.org/10.1016/j.oregeorev.2016.07.019

Galbraith CG, Clarke BD, Trumbull RB, Wiedenbeck M (2009) Assessment of tourmaline compositions as an indicator of emerald mineralization at the tsa da glisza prospect, Yukon Territory, Canada. Econ Geol 104:713-731. https://doi.org/10.2113/ gsecongeo.104.5.713

Gonçalves MA, Mateus A (2019) Delimiting geochemical anomalies in the exploration of covered deposits with multifractal methods and using stream sediment data from the Iberian Pyrite Belt, Southwest
Iberia. Ore Geol Rev 112:103018. https://doi.org/10.1016/j. oregeorev.2019.103018

Gonçalves MA, Mateus A, Pinto F, Vieira R (2018) Using multifractal modelling, singularity mapping, and geochemical indexes for targeting buried mineralization: application to the W-Sn Panasqueira ore-system, Portugal. J Geochem Explor 189:42-53. https://doi.org/10.1016/j.gexplo.2017.07.008

Green TH, Adam J (2003) Experimentally-determined trace element characteristics of aqueous fluid from partially dehydrated mafic oceanic crust at $3.0 \mathrm{GPa}, 650-700^{\circ} \mathrm{C}$. Eur J Mineral 15:815-830. https:// doi.org/10.1127/0935-1221/2003/0015-0815

Grunsky EC, de Caritat P (2019) State-of-the-art analysis of geochemical data for mineral exploration. Geochem Explor Environ Anal Geochem 2019-031. https://doi.org/10.1144/geochem2019-031

Grunsky EC, Drew LJ, Woodruff LG, Woodruff LGG, Friske PWBWB, Sutphin DMM (2013) Statistical variability of the geochemistry and mineralogy of soils in the Maritime Provinces of Canada and part of the Northeast United States. Geochemistry Explor Environ Anal 13: 249-266. https://doi.org/10.1144/geochem2012-138

Harlaux M (2016) Tungsten and rare-metal (Nb, Ta, Sn) hydrothermal metallogenic systems in the late-Variscan orogenic context: example of the French Massif Central systems. Dissertation, Université de Lorraine. https://tel.archives-ouvertes.fr/tel-01528807

Harlaux M, Mercadier J, Marignac C, Villeneuve J, Mouthier B, Cuney M (2019) Origin of the atypical Puy-les-Vignes W breccia pipe (Massif Central, France) constrained by trace element and boron isotopic composition of tourmaline. Ore Geol Rev 114:103132. https://doi.org/10.1016/j.oregeorev.2019.103132

Hazarika P, Mishra B, Lochan Pruseth K (2017) Trace-element geochemistry of pyrite and arsenopyrite: ore genetic implications for late Archean orogenic gold deposits in southern India. Mineral Mag 81:661-678. https://doi.org/10.1180/minmag.2016.080.128

Heinrich CA (1990) The chemistry of hydrothermal tin(-tungsten) ore deposition. Econ Geol 85:457-481. https://doi.org/10.2113/ gsecongeo.85.3.457

Hron K, Templ M, Filzmoser P (2010) Imputation of missing values for compositional data using classical and robust methods. Comput Stat Data Anal 54:3095-3107. https://doi.org/10.1016/j.csda.2009.11. 023

Huang X-W, Boutroy É, Makvandi S, Beaudoin G, Corriveau L, De Toni AF (2019) Trace element composition of iron oxides from IOCG and IOA deposits: relationship to hydrothermal alteration and deposit subtypes. Mineral Deposita 54:525-552. https://doi.org/10. 1007/s00126-018-0825-1

Jackson RG (2010) Application of 3D geochemistry to mineral exploration. Geochemistry Explor Environ Anal 10:143-156. https://doi. org/10.1144/1467-7873/09-217

Jaques L, Pascal C (2017) Full paleostress tensor reconstruction using quartz veins of Panasqueira Mine, central Portugal; part I: Paleopressure determination. J Struct Geol 102:58-74 0.1016/j.jsg. 2017.07.006

Jiang SY, Yu JM, Lu JJ (2004) Trace and rare-earth element geochemistry in tourmaline and cassiterite from the Yunlong tin deposit, Yunnan, China: implication for migmatitic-hydrothermal fluid evolution and ore genesis. Chem Geol 209:193-213. https://doi.org/10. 1016/j.chemgeo.2004.04.021

Jochum KP, Weis U, Schwager B, Stoll B, Wilson SA, Haug GH, Andreae MO, Enzweiler J (2016) Reference values following ISO guidelines for frequently requested rock reference materials. Geostand Geoanal Res 40:333-350. https://doi.org/10.1111/j. 1751-908X.2015.00392.x

Johan Z, Strnad L, Johan V (2012) Evolution of the Cínovec (Zinnwald) granite cupola, Czech Republic: composition of feldspars and micas, a clue to the origin of W, Sn mineralization. Can Mineral 50:11311148. https://doi.org/10.3749/canmin.50.4.1131 
Kalliomäki H, Wagner T, Fusswinkel T, Sakellaris G (2017) Major and trace element geochemistry of tourmalines from Archean orogenic gold deposits: proxies for the origin of gold mineralizing fluids? Ore Geol Rev 91:906-927. https://doi.org/10.1016/j.oregeorev.2017.08. 014

Kelley DL, Kelley KD, Coker WB, Caughlin B, Doherty ME (2006) Beyond the obvious limits of ore deposits: the use of mineralogical, geochemical, and biological features for the remote detection of mineralization. Econ Geol 101:729-752. https://doi.org/10.2113/ gsecongeo.101.4.729

Kelly WC, Rye RO (1979) Geologic, fluid inclusion, and stable isotope studies of the tin-tungsten deposits of Panasqueira, Portugal. Econ Geol 74:1721-1822. https://doi.org/10.2113/gsecongeo.74.8.1721

Keppler H (1996) Constraints from partitioning experiments on the composition of subduction-zone fluids. Nature 380:237-240. https://doi. org $/ 10.1038 / 380237 \mathrm{a} 0$

Keppler H, Wyllie PJ (1991) Partitioning of Cu, Sn, Mo, W, U, and Th between melt and aqueous fluid in the systems haplogranite- $\mathrm{H} 2 \mathrm{O}-$ $\mathrm{HCl}$ and haplogranite-H2O-HF. Contrib Mineral Petrol 109:139150. https://doi.org/10.1007/BF00306474

Kerrich R, Wyman DA (1997) Review of developments in trace-element fingerprinting of geodynamic settings and their implications for mineral exploration. Aust J Earth Sci 44:465-487. https://doi.org/ 10.1080/08120099708728327

Klemme S, Marschall HR, Jacob DE, Prowatke S, Ludwig T (2011) Trace-element partitioning and boron isotope fractionation between white mica and tourmaline. Can Mineral 49:165-176. https://doi. org/10.3749/canmin.49.1.165

Kovalenko VI, Antipin VS (1980) Element distribution coefficients in ongonites (in Russian). Acad Sci USSR 233:182-186

Krienitz MS, Trumbull RB, Hellmann A, Kolb J, Meyer FM, Wiedenbeck M (2008) Hydrothermal gold mineralization at the Hira Buddini gold mine, India: constraints on fluid evolution and fluid sources from boron isotopic compositions of tourmaline. Mineral Deposita 43:421-434. https://doi.org/10.1007/s00126007-0172-0

Kroner U, Hahn T, Romer RL, Linnemann U (2007) The Variscan orogeny in the Saxo-Thuringian zone; Heterogenous overprint of Cadomian/Paleozoic Peri-Gondwana crust. Spec Pap Evol Rheic Ocean from Avalonian-Cadomian Act Margin to AlleghenianVariscan Collis 423:153-172. https://doi.org/10.1130/2007. 2423(06

Large RR, McGoldrick PJ (1998) Lithogeochemical halos and geochemical vectors to stratiform sediment hosted $\mathrm{Zn}-\mathrm{Pb}-\mathrm{Ag}$ deposits, 1 . Lady Loretta Deposit, Queensland. J Geochem Explor 63:37-56. https://doi.org/10.1016/S0375-6742(98)00013-2

Launay G, Sizaret S, Guillou-Frottier L, Fauguerolles C, Champallier R, Gloaguen E (2018) Deciphering fluid flow at the magmatichydrothermal transition: a case study from the world-class Panasqueira W-Sn- $(\mathrm{Cu})$ ore deposit (Portugal). Earth Planet Sci Lett 499:1-12. https://doi.org/10.1016/j.epsl.2018.07.012

Lecumberri-Sanchez P, Vieira R, Heinrich CAA, Pinto F, W lle M (2017) Fluid-rock interaction is decisive for the formation of tungsten deposits. Geology 45:579-582. https://doi.org/10.1130/G38974.1

Legros H, Marignac C, Mercadier J, Cuney M, Richard A, Wang RC, Charles N, Lespinasse MY (2016) Detailed paragenesis and Li-mica compositions as recorders of the magmatic-hydrothermal evolution of the Maoping W-Sn deposit (Jiangxi, China). Lithos 264:108-124. https://doi.org/10.1016/j.lithos.2016.08.022

Legros H, Marignac C, Tabary T, Mercadier J, Richard A, Cuney M, Wang R-C, Charles N, Lespinasse M-Y (2018) The ore-forming magmatic-hydrothermal system of the Piaotang W-Sn deposit (Jiangxi, China) as seen from Li-mica geochemistry. Am Mineral 103:39-54. https://doi.org/10.2138/am-2018-6196

Li J, Huang X-L, He P-L, Li W-X, Yu Y, Chen L (2015) In situ analyses of micas in the Yashan granite, South China: constraints on magmatic and hydrothermal evolutions of $\mathrm{W}$ and $\mathrm{Ta}-\mathrm{Nb}$ bearing granites. Ore Geol Rev 65:793-810. https://doi.org/10.1016/j. oregeorev.2014.09.028

Lichtervelde M, Grégoire M, Linnen RL, Béziat D, Salvi S (2008) Trace element geochemistry by laser ablation ICP-MS of micas associated with Ta mineralization in the Tanco pegmatite, Manitoba, Canada. Contrib Mineral Petrol 155:791-806. https://doi.org/10.1007/ s00410-007-0271-z

LNEG (2010) Carta Geológica de Portugal à escala 1:1 000000

Lowell JD, Guilbert JM (1970) Lateral and vertical alterationmineralization zoning in porphyry ore deposits. Econ Geol 65: 373-408. https://doi.org/10.2113/gsecongeo.65.4.373

Luz F, Mateus A, Figueiras J, Tassinari CCG, Ferreira E, Gonçalves L (2019) Recognizing metasedimentary sequences potentially hosting concealed massive sulfide accumulations in the Iberian Pyrite Belt using geochemical fingerprints. Ore Geol Rev 107:973-998. https:// doi.org/10.1016/j.oregeorev.2019.03.020

Makvandi S, Ghasemzadeh-Barvarz M, Beaudoin G, Grunsky EC, Beth McClenaghan M, Duchesne C (2016a) Principal component analysis of magnetite composition from volcanogenic massive sulfide deposits: case studies from the Izok Lake (Nunavut, Canada) and Halfmile Lake (New Brunswick, Canada) deposits. Ore Geol Rev 72:60-85. https://doi.org/10.1016/j.oregeorev.2015.06.023

Makvandi S, Ghasemzadeh-Barvarz M, Beaudoin G, Grunsky EC, McClenaghan MB, Duchesne C, Boutroy E (2016b) Partial least squares-discriminant analysis of trace element compositions of magnetite from various VMS deposit subtypes: application to mineral exploration. Ore Geol Rev 78:388-408. https://doi.org/10.1016/j. oregeorev.2016.04.014

Makvandi S, Beaudoin G, Beth McClenaghan M, Quirt D, Ledru P (2019) PCA of Fe-oxides MLA data as an advanced tool in provenance discrimination and indicator mineral exploration: case study from bedrock and till from the Kiggavik U deposits area (Nunavut, Canada). J Geochem Explor 197:199-211. https://doi.org/10.1016/j. gexplo.2018.11.013

Manning DAC, Henderson P (1984) The behaviour of tungsten in granitic melt-vapour systems. Contrib Mineral Petrol 86:286-293. https://doi.org/10.1007/BF00373674

Marschall HR (2005) Lithium, beryllium and boron in high-pressure metamorphic rocks from Syros (Greece). Dissertation, RuprechtKarls-Universität Heidelberg https://doi.org/10.11588/heidok. 00005634

Martínez Catalán JR, Arenas R, Díaz García F, Cuadra PG, GómezBarreiro J, Abati J, Castiñeiras P, Fernández-Suárez J, Martínez SS, Andonaegui P, Clavijo EG, Montes AD, Pascual FJR, Aguado BV (2007) Space and time in the tectonic evolution of the northwestern Iberian massif: implications for the Variscan belt. Geol Soc Am Memoir 200:403-423. https://doi.org/10.1130/2007.1200(21

Mathieu L (2018) Quantifying hydrothermal alteration: a review of methods. Geosciences 8:245. https://doi.org/10.3390/ geosciences 8070245

McClenaghan MB, Layton-Matthews D (2017) Application of indicator mineral methods to bedrock and sediments. Geol Surv Can Open File 8345:2017, 86 pages. https://doi.org/10.4095/306305

Melzer S, Wunder B (2001) K-Rb-Cs partitioning between phlogopite and fluid: experiments and consequences for the LILE signatures of island arc basalts. Lithos 59:69-90. https://doi.org/10.1016/S00244937(01)00061-5

Montreuil J-F, Corriveau L, Grunsky EC (2013) Compositional data analysis of hydrothermal alteration in IOCG systems, Great Bear magmatic zone, Canada: to each alteration type its own geochemical signature. Geochem Explor Environ Anal 13:229-247. https://doi. org/10.1144/geochem2011-101

Neiva AMR (1987) Geochemistry of Greisenized granites and metasomatic schist of tungsten-tin deposits in Portugal. In: Chemical 
transport in metasomatic processes. Springer Netherlands, Dordrecht, pp 681-699

Neiva AMR, Silva MMVG, Gomes MEP (2007) Crystal chemistry of tourmaline from Variscan granites, associated tin-tungsten- and gold deposits, and associated metamorphic and metasomatic rocks from northern Portugal. Neues Jahrb für Mineral - Abhandlungen 184: 45-76. https://doi.org/10.1127/0077-7757/2007/0080

Oliveira JT, Pereira E, Ramalho M et al (1992) Carta Geológica de Portugal na escala 1:500 000. Norte, Folha

Ordóñez-Calderón JC, Gelcich S (2018) Machine learning strategies for classification and prediction of alteration facies: examples from the Rosemont Cu-Mo-Ag skarn deposit, SE Tucson Arizona. J Geochem Explor 194:167-188. https://doi.org/10.1016/j.gexplo. 2018.07.020

Paton C, Hellstrom J, Paul B, Woodhead J, Hergt J (2011) Iolite: freeware for the visualisation and processing of mass spectrometric data. $\mathrm{J}$ Anal At Spectrom 26:2508. https://doi.org/10.1039/c1ja10172b

Pawlowsky-Glahn V, Egozcue JJ, Tolosana-Delgado R (2015) Modelling and analysis of compositional data. John Wiley \& Sons, Ltd, Chichester. https://doi.org/10.1002/9781119003144

Pinto FM (2014) Estudo da distribuição do Estanho na Mina da Panasqueira. Dissertation, Universidade do Porto. https://sigarra. up.pt/fmup/pt/pub_geral.pub_view?pi pub_base_id=34260

Polya DA (1989) Chemistry of the main-stage ore-forming fluids of the Panasqueira W-Cu (Ag)-Sn deposit, Portugal: implications for models of ore genesis. Econ Geol 84:1134-1152. https://doi.org/ 10.2113/gsecongeo.84.5.1134

Polya DA, Foxford KA, Stuart F, Boyce A, Fallick AE (2000) Evolution and paragenetic context of low $\delta \mathrm{D}$ hydrothermal fluids from the Panasqueira W-Sn deposit, Portugal: new evidence from microthermometric, stable isotope, noble gas and halogen analyses of primary fluid inclusions. Geochim Cosmochim Acta 64:33573371. https://doi.org/10.1016/S0016-7037(00)00459-2

Pretorius W, Weis D, Williams G, Hanano D, Kieffer B, Scoates J (2006) Complete trace elemental characterisation of granitoid (USGS G-2, GSP-2) reference materials by high resolution inductively coupled plasma-mass spectrometry. Geostand Geoanal Res 30:39-54. https://doi.org/10.1111/j.1751-908X.2006.tb00910.x

REFLEX (2019) ioGASTM 7.0., IMDEX limited [computer software] https://reflexnow.com/iogas/

Ribeiro A, Quesada C, Dallmeyer RD (1990) Geodynamic evolution of the Iberian Massif. In: Dallmeyer RD, Garcia EM (eds) PreMesozoic geology of Iberia. IGCP-Project 233 (Terranes in the Circum-Atlantic Paleozoic Orogens). Springer, Berlin, Heidelberg. https://doi.org/10.1007/978-3-642-83980-1_28

Roda E, Keller P, Pesquera A, Fontan F (2007) Micas of the muscovitelepidolite series from Karibib pegmatites, Namibia. Mineral Mag 71:41-62. https://doi.org/10.1180/minmag.2007.071.1.41

Romer RL, Hahne K (2010) Life of the Rheic Ocean: scrolling through the shale record. Gondwana Res 17:236-253. https://doi.org/10. 1016/j.gr.2009.09.004

Rudnick RL, Gao S (2014) Composition of the continental crust. In: Holland HD, Turekian KK (eds) Treatise on geochemistry 2nd ed. Elsevier, pp 1-64. https://doi.org/10.1016/B0-08-043751-6/030164

Schmidt C (2018) Formation of hydrothermal tin deposits: Raman spectroscopic evidence for an important role of aqueous Sn (IV) species. Geochim Cosmochim Acta 220:499-511. https://doi.org/10.1016/j. gca.2017.10.011

Schröcke H, Trumm A, Hochleitner R (1984) Über den transport von Wolfram und den Absatz von Wolfram-Doppel-Oxiden in fluiden wässrigen Lösungen. The transport of tungsten and the deposition of tungsten double oxides in fluid, aqueous solutions. Geochim Cosmochim Acta 48:1791-1805. https://doi.org/10.1016/00167037(84)90033-4
Soltani Dehnavi A, Lentz DR, McFarlane CRM, Walker JA (2018) Quantification of fluid-mobile elements in white mica by LA-ICPMS: from chemical composition to a potential micro-chemical vectoring tool in VMS exploration. J Geochem Explor 188:290-307. https://doi.org/10.1016/j.gexplo.2018.01.017

Štemprok M (1980) Tin and tungsten deposits of the west-central European Variscides. Proc Fifth Quadrenn IAGOD Symp 1:495512

Su Z-K, Zhao X-F, Li X-C, Zhou M-F (2016) Using elemental and boron isotopic compositions of tourmaline to trace fluid evolutions of IOCG systems: the worldclass Dahongshan $\mathrm{Fe} \mathrm{Cu}$ deposit in SW China. Chem Geol 441:265-279. https://doi.org/10.1016/j. chemgeo.2016.08.030

Thadeu D (1979) Le gisement stanno-wolframifère de Panasqueira (Portugal). Chron Rech Min 450:35-42

Tischendorf G, Gottesmann B, Förster H-J, Trumbull RB (1997) On Libearing micas: estimating $\mathrm{Li}$ from electron microprobe analyses and an improved diagram for graphical representation. Mineral Mag 61: 809-834. https://doi.org/10.1180/minmag.1997.061.409.05

Trumbull RB, Garda GM, Xavier RP, Cavalcanti JAD, Codeço MS (2019) Tourmaline in the Passagem de Mariana gold deposit (Brazil) revisited: major-element, trace-element and B-isotope constraints on metallogenesis. Mineral Deposita 54:395-414. https:// doi.org/10.1007/s00126-018-0819-Z

Ugidos JM, Sánchez-Santos JM, Barba P, Valladares MI (2010) Upper Neoproterozoic series in the Central Iberian, Cantabrian and West Asturian Leonese zones (Spain): geochemical data and statistical results as evidence for a shared homogenised source area. Precambrian Res 178:51-58. https://doi.org/10.1016/j.precamres. 2010.01.009

Uribe-Mogollon C, Maher K (2018) White mica geochemistry of the copper cliff porphyry cu deposit: insights from a vectoring tool applied to exploration. Econ Geol 113:1269-1295. https://doi.org/ 10.5382/econgeo.2018.4591

USGS (2019) Mineral commodity summaries. Washington DC

Van Den Boogaart KG, Tolosana-Delgado R, Bren M (2006) Concepts for handling of zeros and missing values in compositional data. In: IAMG 2006 - 11th International Congress for Mathematical Geology: Quantitative Geology from Multiple Sources. pp 1-4

van Hinsberg VJ (2011) Preliminary experimental data on trace-element partitioning between tourmaline and silicate melt. Can Mineral 49: 153-163. https://doi.org/10.3749/canmin.49.1.153

van Hinsberg VJ, Migdisov AA, Williams-Jones AE (2010) Reading the mineral record of fluid composition from element partitioning. Geology 38:847-850. https://doi.org/10.1130/G31112.1

van Hinsberg VJ, Henry DJ, Marschall HR (2011) Tourmaline: an ideal indicator of its host environment. Can Mineral 49:1-16. https://doi. org/10.3749/canmin.49.1.1

van Hinsberg VJ, Franz G, Wood BJ (2017) Determining subductionzone fluid composition using a tourmaline mineral probe. Geochemical Perspect Lett:160-169. https://doi.org/10.7185/ geochemlet.1719

Verbovšek T (2011) A comparison of parameters below the limit of detection in geochemical analyses by substitution methods. RMZMater Geoenviron 4:393-404

Villaseca C, Merino E, Oyarzun R, Orejana D, Pérez-Soba C, Chicharro E (2014) Contrasting chemical and isotopic signatures from Neoproterozoic metasedimentary rocks in the Central Iberian Zone (Spain) of pre-Variscan Europe: implications for terrane analysis and Early Ordovician magmatic belts. Precambrian Res 245:131145. https://doi.org/10.1016/j.precamres.2014.02.006

Wheeler A (2016) Report in NI 43-101 technical report on the mineral resources and reserves of the Panasqueira Mine, Portugal. Cornwall

Wilkinson JJ, Chang Z, Cooke DR, Baker MJ, Wilkinson CC, Inglis S, Chen H, Gemmell JB (2015) The chlorite proximitor: a new tool for 
detecting porphyry ore deposits. J Geochem Explor 152:10-26. https://doi.org/10.1016/j.gexplo.2015.01.005

Wood SA, Samson IM (2000) The hydrothermal geochemistry of tungsten in granitoid environments: I. Relative solubilities of ferberite and scheelite as a function of T, P, pH, and $\mathrm{mNaCl}$. Econ Geol 95: 143-182. https://doi.org/10.2113/gsecongeo.95.1.143

Wunder B, Melzer S (2003) Experimental evidence on phlogopitic mantle metasomatism induced by phengite dehydration. Eur J Mineral 15:641-647. https://doi.org/10.1127/0935-1221/2003/0015-0641

Xie L, Wang RC, Groat LA, Zhu JC, Huang FF, Cempírek J (2015) A combined EMPA and LA-ICP-MS study of Li-bearing mica and SnTi oxide minerals from the Qiguling topaz rhyolite (Qitianling District, China): the role of fluorine in origin of tin mineralization. Ore Geol Rev 65:779-792. https://doi.org/10.1016/j.oregeorev. 2014.08.013

Yang J, Cheng Q (2014) A comparative study of independent component analysis with principal component analysis in geological objects identification. Part II: a case study of Pinghe District, Fujian, China. J Geochem Explor 149:136-146. https://doi.org/10.1016/j. gexplo.2014.11.014
Yavuz F, Iskenderoğlu A, Jiang SY (1999) Tourmaline compositions from the Salikvan porphyry Cu-Mo deposit and vicinity, northeastern Turkey. Can Mineral 37:1007-1023

Zajacz Z, Halter WE, Pettke T, Guillong M (2008) Determination of fluid/melt partition coefficients by LA-ICPMS analysis of coexisting fluid and silicate melt inclusions: controls on element partitioning. Geochim Cosmochim Acta 72:2169-2197. https:// doi.org/10.1016/j.gca.2008.01.034

Zall F, Tahmasbi Z, Jiang S-Y, Danyushevsky LV, Harris C (2019) Elemental and B-O-H isotopic compositions of tourmaline and associated minerals in biotite-muscovite granite of Mashhad, NE Iran: constraints on tourmaline genesis and element partitioning. Lithos 324-325:803-820. https://doi.org/10.1016/j.lithos.2018.12.012

Zhu C, Sverjensky DA (1991) Partitioning of F-Cl-OH between minerals and hydrothermal fluids. Geochim Cosmochim Acta 55:1837-1858. https://doi.org/10.1016/0016-7037(91)90028-4

Publisher's note Springer Nature remains neutral with regard to jurisdictional claims in published maps and institutional affiliations. 